\title{
Geochemistry of granitic aplite-pegmatite dykes and sills and their minerals from the Gravanho-Gouveia area in Central Portugal
}

\author{
Ana Margarida Ribeiro Neiva ${ }^{\mathrm{a}, \mathrm{b}, *}$, Carlos Leal Gomes ${ }^{\mathrm{c}}$, Paulo Bravo Silva ${ }^{\mathrm{d}}$, \\ Maria Elisa Preto Gomes ${ }^{\mathrm{e}}$, António Carlos Tavares dos Santos ${ }^{\mathrm{a}, \mathrm{b}}$ \\ ${ }^{a}$ GeoBioTec, Department of Geosciences, University of Aveiro, 3810-193 Aveiro, Portugal \\ ${ }^{\mathrm{b}}$ Department of Earth Sciences, University of Coimbra, 3030-790, Coimbra, Portugal \\ ${ }^{\mathrm{c}}$ Department of Earth Sciences, University of Minho, Gualtar, 4710-057, Braga, Portugal \\ ${ }^{\mathrm{d}}$ União Temporária de Empresas IGME-LNEG-IIA, 4466-956 S. Mamede de Infesta, Portugal

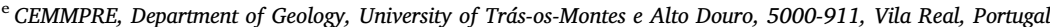

\section{A R T I C L E I N F O}

\section{Keywords:}

Variscan granites

Pegmatites

Feldspars

Micas

Fractionation series

Cassiterite

Hydrothermal fluids

\begin{abstract}
A B S T R A C T
Two distinct series of Variscan granitic rocks have been distinguished in the Gravanho-Gouveia area of Portugal, based on field work, variation diagrams for major and trace elements, rare earth patterns and $\delta^{18} \mathrm{O}$ versus total $\mathrm{FeO}$ diagram of rocks, anorthite content of plagioclase, $\mathrm{BaO}$ and $\mathrm{P}_{2} \mathrm{O}_{5}$ contents of feldspars and $\mathrm{Al}^{\mathrm{VI}}$ versus $\mathrm{Fe}^{2+}$ diagram for magmatic muscovite. One series consists of a late-orogenic porphyritic biotite $>$ muscovite granite (G1), less evolved beryl-columbite pegmatites and more evolved beryl-columbite pegmatites showing gradational contacts. The other series consists of post-orogenic porphyritic muscovite $>$ biotite granodiorite to granite (G2), slightly porphyritic muscovite > biotite granite (G3) and lepidolite pegmatites. In each series, pegmatites are derived from the parent granite magma by fractional crystallization of quartz, plagioclase, Kfeldspar, biotite and ilmenite. Some metasomatic effects occur like muscovite replacing feldspars, chlorite in pegmatites of the first series and a late muscovite in pegmatites of the second series, probably due to hydrothermal fluids. The lepidolite pegmatites contain cassiterite and two generations of rutile. The first magmatic generation consists of homogeneous crystals and the second generation occurs as heterogeneous zoned crystals derived from hydrothermal fluids. The beryl-columbite pegmatites and lepidolite pegmatites also contain the first magmatic generation and the late hydrothermal generation of zoned columbite-group minerals. More evolved beryl-columbite pegmatites were converted into episyenite by intense hydrothermal alteration and regional circulation of fluids in the granitic rocks.
\end{abstract}

\section{Introduction}

Granitic pegmatites, their inner-zonings and minerals have been studied by several authors (e.g., Černý et al., 1985a, b, 2005; London, 2008; London and Morgan, 2012; Neiva, 2013; Neiva and Ramos, 2010; Roda-Robles et al., 2012, 2016). The origin of granitic pegmatites is mainly attributed to the differentiation of a granite magma. However, a few other authors have contested that origin for LCT pegmatites (Černý and Ercit, 2005) and suggest that they result from anatexis (e.g., Stewart, 1978; Bongiolio et al., 2016; Simons et al., 2016).
Granitic aplite-pegmatites and their minerals from three areas of central Portugal, in the Central Iberian Zone, have been studied and result from fractional crystallization of quartz, plagioclase, K-feldspar, biotite and ilmenite of a two-mica granite magma in each area, supported by modelling of major and trace elements (Neiva et al., 2008, 2012; Neiva and Ramos, 2010).

The fourth area chosen for study, the Gravanho-Gouveia area, is significantly different from those already studied, the Arcozelo da Serra area, Guarda-Belmonte area and Sabugal area, because pegmatites often are metasomatically altered and episyenitization occurs in the area. In general, it is difficult to obtain chemical analyses of metaso-

\footnotetext{
* Corresponding author at: GeoBioTec, Department of Geosciences, University of Aveiro, 3810-193 Aveiro, Portugal.

E-mail address: neiva@dct.uc.pt (A.M.R. Neiva).
} 

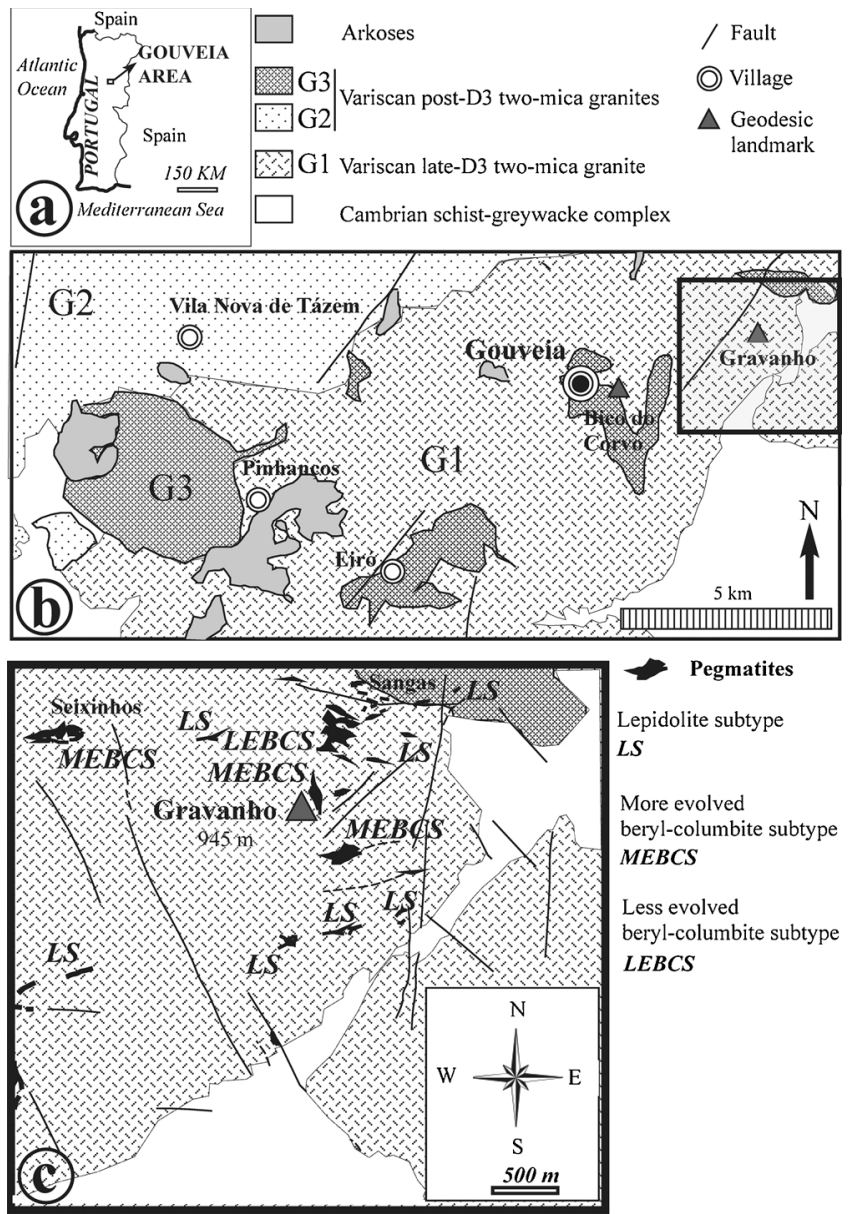

Fig. 1. Geological framework and field relations for granites and pegmatites. a. location of the studied area; $b$. field relations between granites and host-rocks enhancing the location of the major pegmatite field at the surroundings of Gravanho landmark; c. field distribution of the outcropping main types of pegmatites.

matic pegmatites and determine from which primary minerals the secondary minerals were derived. Therefore, papers on this subject are rare, as mentioned in London (2008).

The present paper reports the mineralogy, geochemistry and petrology of granites, dykes and sills composed of both aplite and pegmatite, which are referred to as aplite-pegmatites or simply pegmatites, from the Gravanho-Gouveia area to understand their origin. Wholerock hydrothermal alteration of pegmatites is also studied.

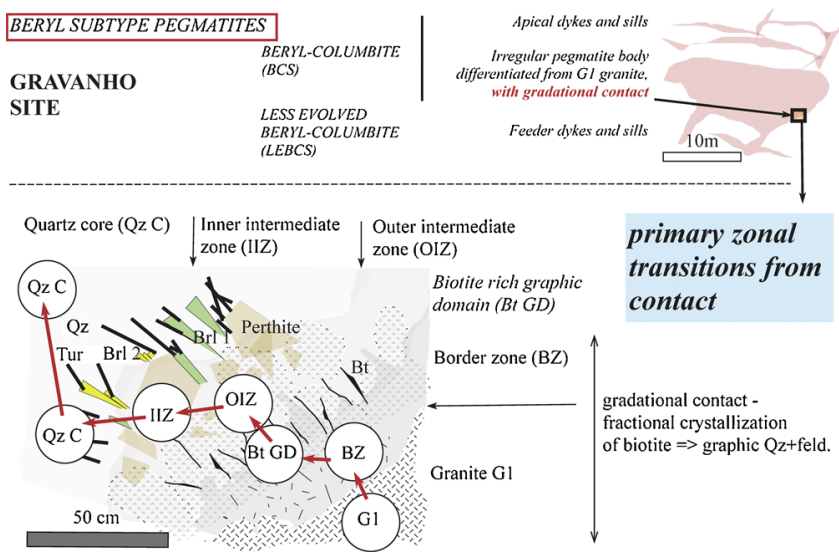

Fig. 2. Sketch of the vertical section for the structure of in situ differentiated inner-granite, beryl subtype pegmatites, in the Gravanho site, with detail of gradational transition between the granite G1 and the zoned pegmatite. Qz quartz, Brl - beryl (1- blue, 2- yellow); Tur - tourmaline; Bt - biotite. BZ Border Zone, BGD - Biotite-rich Graphic Domain, OIZ - Outer Intermediate Zone, IIZ - Inner Intermediate Zone, Qz C - Quartz Core. Mineral abbreviations are as in Whitney and Evans (2010).

\section{Geology}

The Iberian Massif corresponds to the south-western extension of the European Variscan Belt. This massif is rich in Carboniferous and Permian plutonic rocks (e.g. Castro et al., 2002). The Gravanho-Gouveia area is part of the Central Iberian Zone, which is the innermost zone of the Iberian Massif (e.g. Farias et al., 1987).

In the Gravanho-Gouveia area, granites intruded the Cambrian schist-greywacke complex. The age of these granites was determined by the U-Th-Pb monazite method using SHRIMP (Neiva et al., 2009). The age of the coarse- to very coarse-grained late-orogenic porphyritic biotite $>$ muscovite granite (G1) is $301.4 \pm 2.6 \mathrm{Ma}$, while the coarsegrained porphyritic muscovite $>$ biotite granodiorite to granite (G2) and medium- to coarse-grained slightly porphyritic muscovite $>$ biotite granite (G3) are post-orogenic (Fig. 1a, b). The age of the granite G2 is $288.6 \pm 2.5 \mathrm{Ma}$. The contacts between granite G1 and granites G2 and G3 are sharp, while granite G2 passes gradually to granite G3.

Two principal types of aplite-pegmatite dykes and sills intruded the granite G1: (i) aplite-pegmatites of the beryl-columbite subtype (rareelement class) that form larger irregular bodies, and (ii) lepidolite subtype pegmatites (LCT complex type, Černý and Ercit, 2005) that form numerous tabular bodies (Fig. 1c, Table 1). The relatively less evolved beryl-columbite aplite-pegmatites form dykes and sills that predominate at the lower topographic levels of the inner-granite pegmatite field (Fig. 2). Locally they are followed upwards to the confluence with irregular more evolved beryl-columbite aplite-pegmatites,

Table 1

Pegmatite characteristics at the outcrop scale from de Gravanho-Gouveia area, central Portugal.

\begin{tabular}{|c|c|c|c|c|}
\hline aplite- pegmatite subtypes & approximate number in pegmatite field & shape & size - vertical width / extension & internal structure \\
\hline LS pegmatites & 28 & tabular & $<2 \mathrm{~m} / 10-100 \mathrm{~m}$ & layered \\
\hline MEBCS pegmatites & 2 & irregular & $5-20 \mathrm{~m} / 40 \mathrm{~m}$ & zoned \\
\hline $\begin{array}{l}\text { LEBCS } \\
\text { pegmatites }\end{array}$ & 11 & tabular to lens-shaped & $1-5 \mathrm{~m} / 30-150 \mathrm{~m}$ & $\begin{array}{l}\text { homogeneous } \\
\text { with comb-border }\end{array}$ \\
\hline
\end{tabular}

LEBCS - less evolved beryl-columbite; MEBCS - more evolved beryl-columbite; LS - lepidolite. 
Table 2

Mineral assemblages in differentiated internal structures of aplite-pegmatites from the Gravanho-Gouveia area, central Portugal.

\begin{tabular}{|c|c|c|c|c|}
\hline $\begin{array}{l}\text { aplite- pegmatite } \\
\text { subtypes }\end{array}$ & internal units & $\begin{array}{l}\text { essential minerals (abundance: }+ \text { to } \\
+++++ \text { ) }\end{array}$ & crystal sizes & approximate sequence of crystallization \\
\hline \multirow[t]{6}{*}{ Lepidolite } & $\begin{array}{c}\text { border } \\
\text { comb structure }\end{array}$ & $\begin{array}{l}\text { muscovite }(+++) \\
\text { perthite }(++) \\
\text { albite }(++) \\
\text { quartz }(++)\end{array}$ & $\begin{array}{l}<3 \mathrm{~cm} \\
<3 \mathrm{~cm} \\
<3 \mathrm{~cm} \\
<2 \mathrm{~cm}\end{array}$ & muscovite \pm microcline $=>$ albite \pm quartz \\
\hline & inner layers & albite $(++$ to ++++$)$ & $<2 \mathrm{~cm}$ & $\begin{array}{l}\text { topaz } \pm \text { montebrasite }=>\text { lepidolite } \pm \text { albite }=> \\
\text { lepidolite } \pm \text { quartz }\end{array}$ \\
\hline & & lepidolite $(<++++)$ & $<1 \mathrm{~cm}$ & \\
\hline & & topaz $(+)$ & $<6 \mathrm{~cm}$ & \\
\hline & & montebrasite-ambligonite $(+)$ & $<6 \mathrm{~cm}$ & \\
\hline & & quartz $(++)$ & $<6 \mathrm{~cm}$ & \\
\hline \multirow{5}{*}{$\begin{array}{l}\text { More evolved beryl- } \\
\text { columbite }\end{array}$} & border & biotite $(++)$ & $<3 \mathrm{~cm}$ & biotite $=>$ graphic assemblage \\
\hline & $\begin{array}{l}\text { transition to outer } \\
\text { intermediate zone }\end{array}$ & $\begin{array}{c}\text { perthite /quartz graphic }(++++) \\
\text { biotite }(+)\end{array}$ & $\begin{array}{l}<60 \mathrm{~cm} \\
<30 \mathrm{~cm}\end{array}$ & $\begin{aligned} \text { biotite } & =>\text { muscovite }=>\text { graphic assemblage } \\
& =>\text { perthite } \pm \text { albite } \pm \text { quartz }\end{aligned}$ \\
\hline & & $\begin{array}{c}\text { perthite /quartz graphic }(++) \\
\text { muscovite }(++) \\
\text { perthite }(++) \\
\text { albite }(++) \\
\text { quartz }(+)\end{array}$ & $\begin{array}{l}<40 \mathrm{~cm} \\
<15 \mathrm{~cm} \\
<40 \mathrm{~cm} \\
<3 \mathrm{~cm} \\
<5 \mathrm{~cm}\end{array}$ & \\
\hline & inner intermediate & $\begin{array}{c}\text { perthite }(+++) \\
\text { muscovite }(+) \\
\text { albite }(++) \\
\text { quartz }(++++) \\
\text { beryl }(+) \\
\text { tourmaline }(+)\end{array}$ & $\begin{array}{l}<35 \mathrm{~cm} \\
<20 \mathrm{~cm} \\
<4 \mathrm{~cm} \\
<50 \mathrm{~cm} \\
<15 \mathrm{~cm} \\
<5 \mathrm{~cm}\end{array}$ & $\begin{array}{l}\text { perthite } \pm \text { albite } \pm \text { muscovite } \\
=>\text { quartz } \pm \text { beryl }=> \\
\text { tourmaline }\end{array}$ \\
\hline & $\begin{array}{l}\text { zone } \\
\text { quartz core }\end{array}$ & $\begin{array}{c}\text { quartz }(++++) \\
\text { beryl }(+) \\
\text { tourmaline }(+)\end{array}$ & $\begin{array}{l}<100 \mathrm{~cm} \\
<30 \mathrm{~cm} \\
<15 \mathrm{~cm}\end{array}$ & $\begin{array}{c}\text { beryl }=>\text { tourmaline }=> \\
\text { quartz }\end{array}$ \\
\hline \multirow[t]{6}{*}{$\begin{array}{l}\text { Less evolved } \\
\text { beryl-columbite }\end{array}$} & border & $\begin{array}{c}\text { tourmaline }(++) \\
\text { biotite }(++) \\
\text { muscovite }(+++) \\
\text { albite } \pm \text { perthite } \pm \text { quartz }(++++)\end{array}$ & $\begin{array}{l}<6 \mathrm{~cm} \\
<6 \mathrm{~cm} \\
<2 \mathrm{~cm} \\
<2 \mathrm{~cm}\end{array}$ & $\begin{array}{l}\text { biotite } \pm \text { tourmaline }=> \\
\text { muscovite }=> \\
\text { albite } \pm \text { perthite } \pm \text { quartz }\end{array}$ \\
\hline & $\begin{array}{l}\text { inner granular to aplitic } \\
\text { groundmass }\end{array}$ & perthite $(+++)$ & $<1 \mathrm{~cm}$ & tourmaline $=>$ perthite $=>$ \\
\hline & & albite $(+++)$ & $<0.5 \mathrm{~cm}$ & albite $=>$ quartz $=>$ \\
\hline & & quartz $(+++)$ & $<0.5 \mathrm{~cm}$ & muscovite \\
\hline & & muscovite $(++)$ & $<0.5 \mathrm{~cm}$ & \\
\hline & & tourmaline $(+)$ & $<0.5 \mathrm{~cm}$ & \\
\hline
\end{tabular}

Note: crystal sizes are suggested by major lengths of their observed sections in outcrops.

which are differentiated in situ. The border structures of feeder dykes and sills indicate differential movement of pegmatite melt through the granite mass with contrasting rheological behaviour. At the feeder veins position, small-scale magmatic structures illustrate the contrasting rheology and motion of pegmatite magmas relative to the granite G1 viscous groundmass. Sharp contacts and host granite feldspar phenocrysts and biotite lamellae are parallel to the pegmatite elongation. This suggests a shear induced differential flux displacement of a pegmatite mush in relation to a incompletely consolidated granite host. At the upper positioned and irregular pegmatite bodies, the gradual transition between granite and pegmatite indicates in situ crystallization and a much more stationary and dynamically stable granite-pegmatite boundary. In contrast, a more stationary inner fractionation in irregular pegmatite bodies produces a centripetal and gradually enlarged inner growth of prismatic and elongated comb crystals, and a centrifugal and gradational transition to the normal grain size of the host granite. Feeders of less evolved beryl-columbite aplite-pegmatites are homogeneous, although an incipient comb structure of black tourmaline might be present at the pegmatite inside the border and nucleated over the sharpest contacts. Zoned primary transitions, from contact inward, occur mainly at the more evolved beryl-columbite aplite-pegmatites and are interpreted as in situ crystallization of a residual melt, without significant compositional or thermodynamic gradients towards the host granite and without signs of relative displacement regarding the emplacement. Only the more evolved beryl-columbite aplite-pegmatites are clearly zoned (Fig. 2, Tables 1 and 2).

The lepidolite (LS) pegmatite sills crosscut irregular bodies of berylcolumbite pegmatites at their apical margins at the upper topographic levels of the pegmatite field. Therefore, they are younger than the less and more evolved beryl-columbite aplite-pegmatites (Fig. 1c). LS sills from the same generation in direct contact with the granite G1 show interface textures typical of non-equilibrium such as strips of zinnwaldite replacing biotite outwards from both contacts in the surrounding granite G1. LS aplite-pegmatites, intruded at the upper granite G1 levels, may reveal a comb layered inner structure of alternating predominantly albite and lepidolite layers. The content of quartz increases 
towards the core, while muscovite and K-feldspar contents are significant only at the border, locally forming a distinct comb (Table 2). In these pegmatites, tourmaline occurs as rare brown crystals $1 \mathrm{~mm}$ in size, or as light coloured (locally gemmy, mainly pinkish in colour) crystals (several centimetres in length and less than a centimetre in width), in some innermost miarolitic voids in association with later cookeite and infilling clay minerals (Leal Gomes, 2010).

\section{Analytical methods}

The major and most trace elements of granites and aplite-pegmatite dykes and sills were determined using X-ray fluorescence (XRF) and the Tertian and Claisse (1982) method, with a precision better than $\pm 1 \%$ for major elements and $\mathrm{Rb}$, and $\pm 4 \%$ for other minor and trace elements. Lithium was determined by atomic absorption spectroscopy with a precision of $\pm 2 \%$. Zinc, $\mathrm{Cu}$ and $\mathrm{Pb}$ were analysed by ICP-AES with a precision of $\pm 5 \%$. Detection limits were $2.5 \mathrm{ppm}$ for Li; $3 \mathrm{ppm}$ for $\mathrm{Nb}$, $\mathrm{Zr}, \mathrm{Y}, \mathrm{Sr}$ and Rb; $4 \mathrm{ppm}$ for $\mathrm{Cu}$; $5 \mathrm{ppm}$ for Ta and Th; $6 \mathrm{ppm}$ for $\mathrm{Zn}, \mathrm{Sn}$ and $\mathrm{Pb} ; 7 \mathrm{ppm}$ for $\mathrm{Ba}$. These determinations were carried out at LNEG, S. Mamede de Infesta, Portugal.

The total $\mathrm{FeO}$ of the granitic rocks was determined by titration with a standardized potassium permanganate solution with a precision of $\pm 1 \%$. For this determination $0.5 \mathrm{~g}$ of a granitic sample was decomposed and dissolved with an acid mixture prepared in another crucible by adding $5 \mathrm{ml}$ of concentrated $\mathrm{H}_{2} \mathrm{SO}_{4}$ to $5 \mathrm{ml}$ of ultra-pure water and then $5 \mathrm{ml}$ of $\mathrm{HF}$ was added. The $\mathrm{F}$ content of these rocks was analysed by selective ion electrode with a precision of $\pm 2 \%$. These determinations for granites were carried out at the Department of Earth Sciences, University of Coimbra, Portugal, whereas those for aplite-pegmatite dykes and sills were done at LNEG, Portugal. Loss on ignition (LOI) for rocks was determined following the method of Lechler and Desilets (1987). The REE concentrations were measured by ICP-MS with a precision of $\pm 5 \%$ in the SGS Laboratory, Toronto, Canada, for granites and at LNEG, for aplite-pegmatite dykes and sills and mutually consistent results by checking the same reference materials. Whole-rock oxygen isotope analyses were performed by gas mass spectrometry using the method of Clayton and Mayeda (1963), with the $\delta^{18} \mathrm{O}$ reproducibility of $\pm 0.2 \%$ using the quartz standard NBS-28, at the Department of Earth Sciences, the University of Western Ontario, Canada.

The major element compositions of minerals from granites were analysed using the Modified Cambrian Geoscan Link System energydispersive system, but selected feldspars and micas were analysed using a Cameca SX100 electron microprobe at the Department of Earth Sciences, University of Manchester, U.K. (Neiva et al., 2009). The electron microprobes were operated at an accelerating voltage of $15 \mathrm{kV}$ and a $15 \mathrm{nA}$ beam current. Detection limits $(3 \delta)$ above mean background were $<0.03 \mathrm{wt} . \%$ oxide for most components, except for $\mathrm{F}$ (0.1 wt.\%), $\mathrm{BaO}(0.06$ wt.\%) and $\mathrm{Cl}(0.01 \mathrm{wt} . \%)$, with counting times of $80 \mathrm{~s}$ for $\mathrm{F}, \mathrm{Cl}$ and $\mathrm{BaO}$. The major element compositions of minerals from aplite-pegmatite dykes and sills were determined using a Cameca Camebax electron microprobe and also a Hyperprobe Jeol JXA-8500 F, operating at $15 \mathrm{kV}$ accelerating voltage and $15 \mathrm{nA}$ and $10 \mathrm{nA}$ beam current, respectively, for the former and the latter instrument. Detection limits (38) above mean background were $0.03 \mathrm{wt} . \%$ oxide, except for $\mathrm{BaO}, \mathrm{Rb}_{2} \mathrm{O}$ and $\mathrm{Cs}_{2} \mathrm{O}(0.06$ wt.\%) and $\mathrm{F}$ (0.1 wt.\%) with counting times of $80 \mathrm{~s}$ for $\mathrm{BaO}, \mathrm{Rb}_{2} \mathrm{O}, \mathrm{Cs}_{2} \mathrm{O}$ and $\mathrm{F}$. After dissolution and dilution, $\mathrm{Be}$ and Li in beryl were determined by ICP-MS with a precision of $\pm 2 \%$ and $\mathrm{H}_{2} \mathrm{O}^{+}$was determined with a Penfield tube and a precision of $\pm 1 \%$. Chemical analyses of cassiterite and rutile were determined using a Cameca Camebax electron microprobe conducted at an accelerating voltage of $15 \mathrm{kV}$ and a beam current of $20 \mathrm{nA}$. The signal of each element was counted for $20 \mathrm{~s}$. Raw-data were corrected using the PAP procedure of Pouchou and Pichoir (1985). These determinations were carried out at LNEG, S. Mamede de Infesta, Portugal. The $\mathrm{Li}_{2} \mathrm{O}$ content of muscovite was calculated using the equation $\mathrm{Li}_{2} \mathrm{O}=0.3935 \mathrm{~F}^{1.236}$, and those of zinnwaldite, trilithionite and polylithionite using the equation $\mathrm{Li}_{2} \mathrm{O}=\left(0.289 \times \mathrm{SiO}_{2}\right)-9.658$ (Tischendorf et al., 1997), but there are some drawbacks of this approach.

The general formula of Henry et al. (2011) for tourmaline was used. Structural formulae were calculated on the basis of 31 anions using the Microsoft Excel ${ }^{\text {Tn }}$ worksheet of Tindle et al. (2002). Boron was assumed to be stoichiometric (e.g., Hawthorne, 1996). All Fe and Mn were assumed to be divalent. The Li concentrations were calculated according to the multiple regression method of Pesquera et al. (2016). The obliquity $\triangle=12.5\left(\mathrm{~d}_{131}-\mathrm{d}_{131}\right)$ was determined by X-ray diffraction patterns of separates of K-feldspar. The error does not exceed \pm 0.003 .

\section{Petrography}

The granites and aplite-pegmatites contain the minerals indicated in Table 3. All granites have a subhedral granular texture and contain phenocrysts of K-feldspar and plagioclase. Anhedral quartz has undulose extinction, is fractured and contains inclusions of all minerals. Kfeldspar and plagioclase are subhedral and show undulose extinction. Micas from the granite G1 show some orientation. Biotite and

Table 3

Minerals of granites and aplite-pegmatites from the Gravanho-Gouveia area, central Portugal.

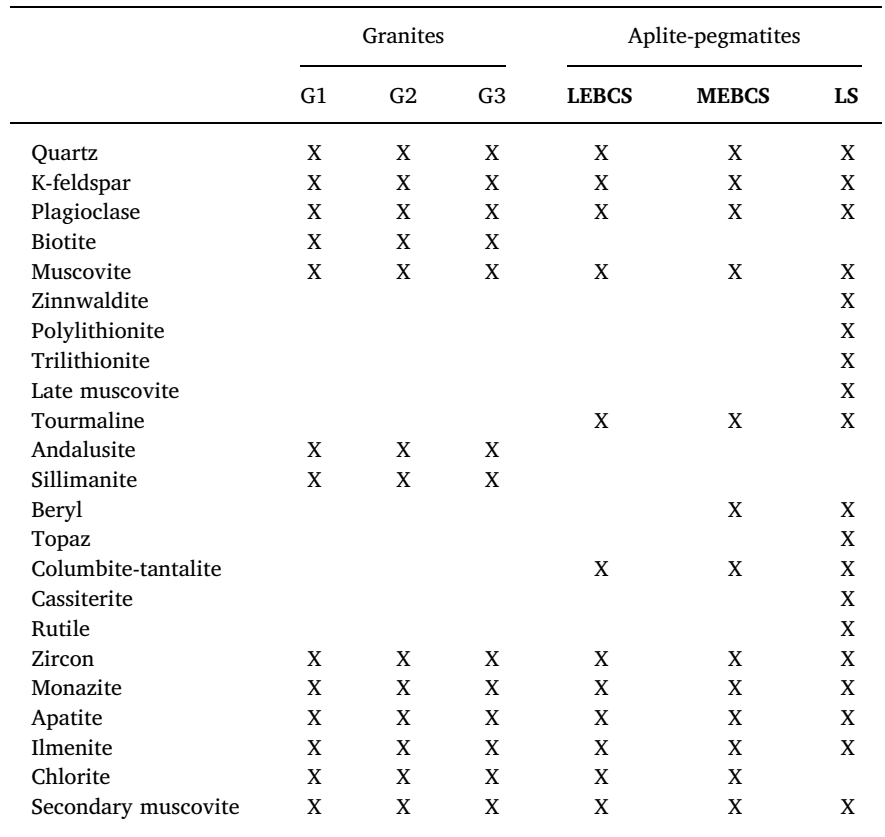

LEBCS - less evolved beryl-columbite, MEBCS - more evolved beryl-columbite, LS - lepidolite. Rare triplite-zwiezelite occurs in MEBCS and rare amblygonitemontebrasite occurs in LS. Both phosphates were identified by XRD. Polylithionite and trilithionite correspond to the lepidolite series. 

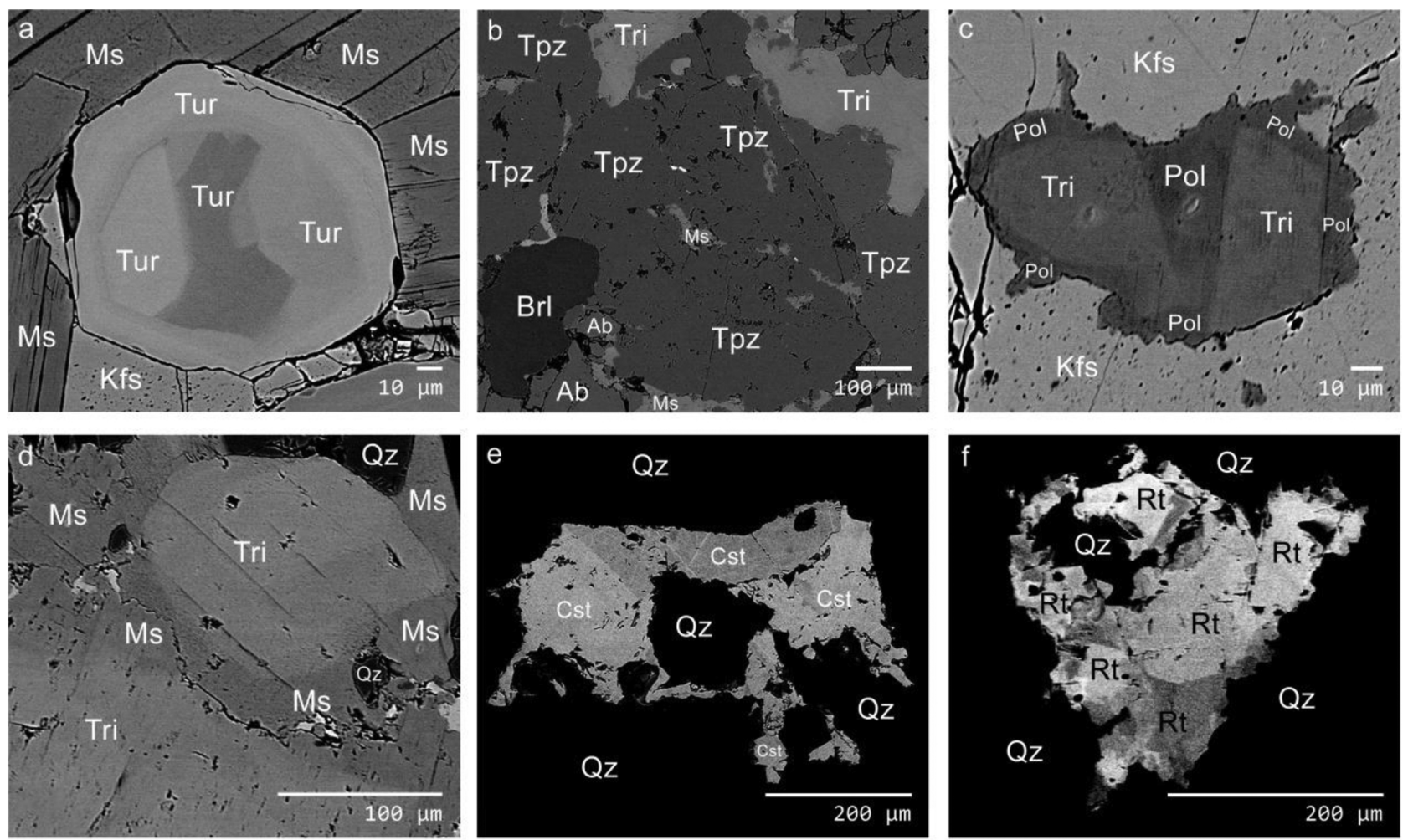

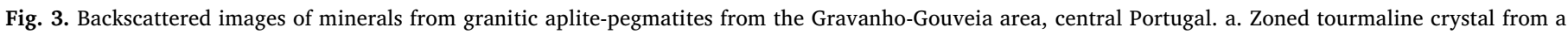

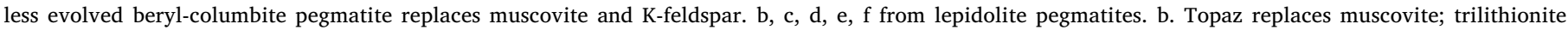

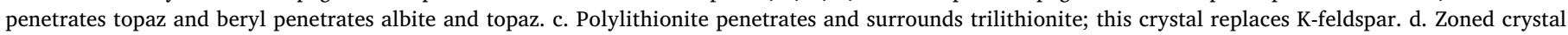

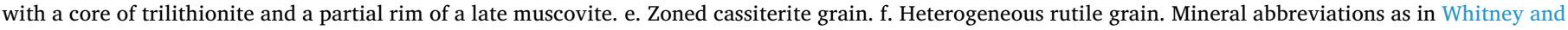

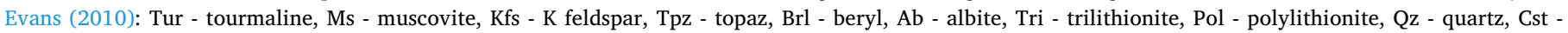
cassiterite, Rt - rutile.

muscovite are subhedral, intergrown and contain inclusions of andalusite, zircon, monazite, apatite and ilmenite. Needles of sillimanite occur in muscovite, they are rarer in feldspar and quartz and occur very rarely in andalusite from the granite G3. Biotite shows some chloritization. Some secondary muscovite replaces plagioclase.

In both the less and more evolved beryl-columbite aplite-pegmatites, quartz is anhedral with undulose extinction and is fractured. Kfeldspar is subhedral and microperthitic microcline. Plagioclase is subhedral, surrounds K-feldspar and muscovite and replaces them. Muscovite is subhedral and contains inclusions of zircon, monazite and apatite. Tourmaline shows anhedral unzoned crystals and zoned crystals (Fig. 3a), which are pleochroic from greenish-brown to light brown. Tourmaline replaces K-feldspar, muscovite and quartz. The first magmatic generation and the second hydrothermal generation of columbite-tantalite were distinguished (Neiva et al., 2015). Some secondary muscovite replaces plagioclase. Subhedral chlorite occurs. In more evolved beryl-columbite aplite-pegmatites, crystals of beryl are subhedral, white, green, blue and yellow in colour. Ilmenite is subhedral and rare.

Lepidolite aplite-pegmatites contain anhedral quartz, showing undulose extinction and fractures. K-feldspar is subhedral and intensively microperthitic microcline. Plagioclase is subhedral, surrounds K-feldspar and muscovite and replaces them. Muscovite is subhedral and contains inclusions of zircon, monazite and apatite. Tourmaline is anhedral, dark in colour and replaces quartz, K-feldspar and muscovite. Topaz contains inclusions of muscovite (Fig. 3b) and replaces muscovite. Trilithionite penetrates topaz (Fig. 3b) and contains inclusions of $\mathrm{K}$-feldspar and albite; it locally replaces K-feldspar, and also is replaced by albite. Beryl is pink in colour and penetrates albite and topaz (Fig. 3b). Polylithionite surrounds and penetrates trilithionite (Fig. 3c). A late muscovite up to $1 \mathrm{~cm}$ in length surrounds trilithionite (Fig. 3d). A late generation of quartz replaces K-feldspar and trilithionite. Ilmenite is rare. Most cassiterite crystals are unzoned, but some show a faint zoning and several crystals show a darker zone and a lighter zone (Fig. 3e). Rutile occurs as homogeneous and heterogeneous grains. The latter have darker and lighter zones (Fig. 3f). Rutile occurs associated with zinnwaldite and apatite at the footwall of the dyke. The first magmatic generation and the second hydrothermal generation of columbite-tantalite were distinguished (Neiva et al., 2015). Some secondary muscovite replaces plagioclase.

Metasomatic rocks resembling episyenite occur in the area. Metasomatism of more evolved beryl-columbite aplite-pegmatites started with an increase in the obliquity of K-feldspar and potassic alteration around perthitic veinlets, and ended with an intensive microclinization and redness of these aplite-pegmatites, loss of quartz and volume and also occurrence of corroded zones filled by epidote, chlorite and hematite and locally by fluorite. Secondary muscovite also occurs. 


\section{Whole-rock geochemistry}

Whole-rock samples were obtained by channel sampling, transversal to the strike of tabular, homogeneous to heterogeneous pegmatites. Representative chemical analyses and trace elements of granites and aplite-pegmatites from the Gravanho-Gouveia area are given in Table 4.

The studied rocks form two distinct evolutionary trends: (i) from granite G1 through the less evolved to the more evolved beryl-columbite pegmatites, and (ii) from granite G2 through granite G3 to lepidolite pegmatites (Fig. 4). The less evolved beryl-columbite pegmatites and more evolved beryl-columbite pegmatites are distinguished mineralogically and chemically from the lepidolite pegmatites. The beryl-columbite pegmatites (analyses 4-7, Table 4) have a higher $\mathrm{Rb}$ content and lower $\mathrm{TiO}_{2}$, total $\mathrm{FeO}, \mathrm{MgO}, \mathrm{CaO}, \mathrm{Zr}, \mathrm{Y}, \mathrm{Sr}, \mathrm{Ba}$ and $\mathrm{Th}$ contents than the granite G1. Variation diagrams of these granitic rocks define the fractionation trends (Fig. 4).

From the granite G2 to the granite G3 and to lepidolite pegmatites, the $\mathrm{F}, \mathrm{Sn}, \mathrm{Li}$ and $\mathrm{Rb}$ contents increase progressively while $\mathrm{TiO}_{2}$, total $\mathrm{FeO}, \mathrm{MgO}, \mathrm{CaO}, \mathrm{K}_{2} \mathrm{O}, \mathrm{Zr}, \mathrm{Y}, \mathrm{Sr}, \mathrm{Ba}$ and $\mathrm{Th}$ contents decrease progressively (analyses 8-16, Table 4). These two granites and pegmatites define similar fractionation trends (Fig. 4). These pegmatites are the richest in $\mathrm{F}, \mathrm{Nb}, \mathrm{Ta}, \mathrm{Sn}, \mathrm{Li}$ and $\mathrm{Rb}$ in the studied area.
The REE contents of selected samples are given in Table 5. Their chondrite normalized REE patterns are subparallel in each series (Fig. 5) and enriched in LREE with respect to HREE $\left(\mathrm{La}_{N} / \mathrm{Yb}_{\mathrm{N}}\right.$ of 8.2-14.8 and $\mathrm{La}_{\mathrm{N}} / \mathrm{Dy}_{\mathrm{N}}$ of 5.1-7.5). The REE contents decrease progressively from granite G1 to the less evolved beryl-columbite pegmatite and the more evolved beryl-columbite pegmatite, and also from granite G2 to granite G3 and lepidolite pegmatites. The granite G2 has the highest $\Sigma$ REE content. The lepidolite pegmatites have the lowest $\Sigma$ REE contents.

The $\delta^{18} \mathrm{O}$ values for granite $\mathrm{G} 1$, the less evolved and the more evolved beryl-columbite pegmatites develop a negative trend in the $\delta^{18} \mathrm{O}$ versus total $\mathrm{FeO}$ diagram, whereas the granites $\mathrm{G} 2$ and $\mathrm{G} 3$ and lepidolite pegmatites develop a parallel trend in this diagram (Fig. 6, Table 6).

Major and trace element concentrations of a metasomatized more evolved beryl-columbite pegmatite are listed in Table 4. This rock sample has higher $\mathrm{Al}_{2} \mathrm{O}_{3}, \mathrm{~K}_{2} \mathrm{O}, \mathrm{F}, \mathrm{Sn}, \mathrm{Rb}$ contents and lower $\mathrm{SiO}_{2}, \mathrm{Nb}$ and $\mathrm{Zn}$ contents than non-metasomatized more evolved beryl-columbite pegmatites.

Table 4

Representative chemical analyses in wt.\% and trace elements in ppm of granites and some granitic aplite-pegmatites from the Gravanho-Gouveia area, central Portugal.

\begin{tabular}{|c|c|c|c|c|c|c|c|c|c|c|c|c|c|c|c|c|c|}
\hline & \multicolumn{3}{|c|}{ Granite G1 } & \multicolumn{2}{|c|}{ LEBCS pegmatites } & \multicolumn{2}{|c|}{ MEBCS pegmatites } & \multicolumn{2}{|c|}{ Granite G2 } & \multicolumn{2}{|c|}{ Granite G3 } & \multicolumn{5}{|c|}{ LS pegmatites } & \multirow{2}{*}{$\begin{array}{l}\text { Metasomatic rock } \\
17\end{array}$} \\
\hline & 1 & 2 & 3 & 4 & 5 & 6 & 7 & 8 & 9 & 10 & 11 & 12 & 13 & 14 & 15 & 16 & \\
\hline $\mathrm{SiO}_{2}$ & 69.36 & 71.44 & 73.69 & 71.39 & 73.11 & 69.56 & 74.66 & 71.96 & 72.88 & 73.30 & 74.83 & 73.39 & 74.34 & 74.41 & 70.73 & 70.68 & 60.48 \\
\hline $\mathrm{TiO}_{2}$ & 0.41 & 0.38 & 0.23 & 0.09 & 0.11 & - & 0.05 & 0.28 & 0.28 & 0.17 & 0.13 & - & - & 0.03 & - & - & 0.25 \\
\hline $\mathrm{Al}_{2} \mathrm{O}_{3}$ & 14.73 & 14.32 & 13.86 & 15.49 & 15.11 & 18.38 & 14.45 & 13.89 & 13.70 & 14.12 & 13.82 & 15.71 & 15.17 & 15.54 & 17.68 & 17.32 & 22.09 \\
\hline $\mathrm{Fe}_{2} \mathrm{O}_{3}$ & 0.51 & 0.46 & 0.32 & 0.78 & 0.74 & 0.15 & 0.32 & 0.40 & 0.30 & 0.32 & 0.38 & 0.24 & 0.12 & 0.13 & 0.12 & 0.08 & 0.26 \\
\hline $\mathrm{FeO}$ & 1.77 & 1.71 & 1.31 & 0.51 & 0.21 & 0.18 & 0.13 & 1.88 & 1.57 & 1.13 & 0.89 & 0.56 & 0.63 & - & - & - & 0.14 \\
\hline $\mathrm{MnO}$ & 0.03 & 0.03 & 0.03 & 0.02 & 0.02 & 0.04 & 0.02 & 0.03 & 0.04 & 0.03 & 0.03 & 0.12 & 0.15 & 0.05 & 0.12 & 0.17 & - \\
\hline $\mathrm{MgO}$ & 0.56 & 0.50 & 0.30 & 0.12 & 0.28 & - & 0.08 & 0.50 & 0.38 & 0.28 & 0.20 & - & - & - & - & - & 0.27 \\
\hline $\mathrm{CaO}$ & 0.96 & 0.83 & 0.59 & 0.30 & 0.24 & 0.04 & 0.05 & 1.28 & 1.03 & 0.67 & 0.60 & 0.11 & 0.12 & 0.10 & 0.11 & 0.09 & 0.51 \\
\hline $\mathrm{Na}_{2} \mathrm{O}$ & 4.22 & 2.79 & 3.01 & 3.17 & 4.18 & 7.17 & 0.53 & 3.15 & 3.36 & 2.99 & 3.12 & 4.34 & 4.54 & 4.78 & 4.84 & 4.72 & 3.36 \\
\hline $\mathrm{K}_{2} \mathrm{O}$ & 5.43 & 5.53 & 4.95 & 4.13 & 4.09 & 1.63 & 6.81 & 5.50 & 4.86 & 4.81 & 4.17 & 3.64 & 2.63 & 3.22 & 3.69 & 3.77 & 9.74 \\
\hline $\mathrm{P}_{2} \mathrm{O}_{5}$ & 0.32 & 0.30 & 0.29 & 0.37 & 0.51 & 0.15 & 0.17 & 0.21 & 0.19 & 0.27 & 0.28 & 0.13 & 0.19 & 0.21 & 0.27 & 0.18 & 0.51 \\
\hline $\mathrm{F}$ & 0.12 & 0.12 & 0.13 & 0.09 & 0.12 & 0.14 & 0.14 & 0.15 & 0.16 & 0.18 & 0.19 & 0.42 & 0.42 & 0.61 & 1.51 & 1.55 & 0.18 \\
\hline \multirow[t]{2}{*}{ LOI } & 1.47 & 1.34 & 1.24 & 2.53 & 0.64 & 1.64 & 2.24 & 1.11 & 1.26 & 1.36 & 1.24 & 1.17 & 1.18 & 0.75 & 1.20 & 1.03 & 1.76 \\
\hline & 99.89 & 99.75 & 99.97 & 98.99 & 99.36 & 99.08 & 99.65 & 100.34 & 100.01 & 99.63 & 99.88 & 99.83 & 99.49 & 99.83 & 100.27 & 99.59 & 99.55 \\
\hline $\mathrm{O} \equiv \mathrm{F}$ & 0.05 & 0.05 & 0.06 & 0.04 & 0.05 & 0.06 & 0.06 & 0.06 & 0.07 & 0.08 & 0.08 & 0.18 & 0.18 & 0.26 & 0.63 & 0.65 & 0.08 \\
\hline Total & 99.84 & 99.70 & 99.91 & 98.95 & 99.31 & 99.02 & 99.59 & 100.28 & 99.94 & 99.55 & 99.80 & 99.65 & 99.31 & 99.57 & 99.64 & 98.94 & 99.47 \\
\hline $\mathrm{A} / \mathrm{CNK}$ & 1.01 & 1.18 & 1.22 & 1.52 & 1.27 & 1.28 & 1.73 & 1.03 & 1.08 & 1.25 & 1.29 & 1.39 & 1.44 & 1.35 & 1.45 & 1.44 & - \\
\hline $\mathrm{Nb}$ & 13 & 12 & 11 & 21 & 12 & 13 & 10 & 18 & 18 & 17 & 19 & 30 & 38 & 29 & 25 & 61 & 8 \\
\hline $\mathrm{Ta}$ & $*$ & $*$ & $*$ & $*$ & $*$ & $*$ & $*$ & $*$ & $*$ & $*$ & $*$ & 7 & 13 & 33 & 26 & 62 & $*$ \\
\hline Zn & 64 & 68 & 45 & 44 & 43 & 36 & 40 & 77 & 73 & 66 & 58 & 116 & 133 & 17 & 31 & 49 & 20 \\
\hline Sn & 12 & 14 & 22 & 25 & 23 & 33 & 35 & 19 & 25 & 29 & 45 & 77 & 114 & 224 & 238 & 404 & 54 \\
\hline $\mathrm{Li}$ & 108 & 104 & 120 & 122 & 122 & 163 & 170 & 179 & 195 & 260 & 320 & 743 & 790 & 1258 & 3345 & 3856 & 158 \\
\hline $\mathrm{Zr}$ & 173 & 164 & 99 & 31 & 24 & 7 & 29 & 161 & 134 & 89 & 65 & 13 & 66 & 10 & 20 & 34 & 99 \\
\hline $\mathrm{Cu}$ & 15 & 13 & $*$ & 34 & 4 & 7 & 8 & 15 & 17 & $*$ & $*$ & $*$ & $*$ & $*$ & $*$ & 4 & 6 \\
\hline $\mathrm{Y}$ & 17 & 15 & 10 & 8 & $*$ & $*$ & $*$ & 27 & 26 & 20 & 16 & $*$ & $*$ & $*$ & $*$ & $*$ & 5 \\
\hline $\mathrm{Sr}$ & 106 & 102 & 65 & 19 & 10 & 7 & 8 & 72 & 65 & 63 & 38 & 5 & 4 & 14 & 14 & 12 & 10 \\
\hline $\mathrm{Pb}$ & 35 & 55 & 23 & 30 & 20 & 24 & 115 & 34 & 22 & 52 & 31 & 13 & 23 & 33 & 23 & 26 & 50 \\
\hline $\mathrm{Ba}$ & 490 & 399 & 210 & 43 & 18 & 21 & 17 & 320 & 297 & 212 & 121 & 16 & 18 & 31 & 27 & 25 & 440 \\
\hline $\mathrm{Rb}$ & 246 & 250 & 258 & 269 & 274 & 316 & 314 & 331 & 340 & 386 & 480 & 853 & 784 & 929 & 1604 & 1803 & 458 \\
\hline Th & 20 & 20 & 11 & $*$ & $*$ & $*$ & $*$ & 32 & 21 & 14 & 10 & $*$ & $*$ & $*$ & $*$ & & 5 \\
\hline
\end{tabular}

LEBCS - less evolved beryl-columbite, MEBCS - more evolved beryl-columbite, LS - lepidolite; - not detected; * below the detection limit. The A/CNK ratio is the molecular $\mathrm{Al}_{2} \mathrm{O}_{3} /\left(\mathrm{CaO}+\mathrm{Na}_{2} \mathrm{O}+\mathrm{K}_{2} \mathrm{O}\right)$, which shows that the granitic rocks are peraluminous. 


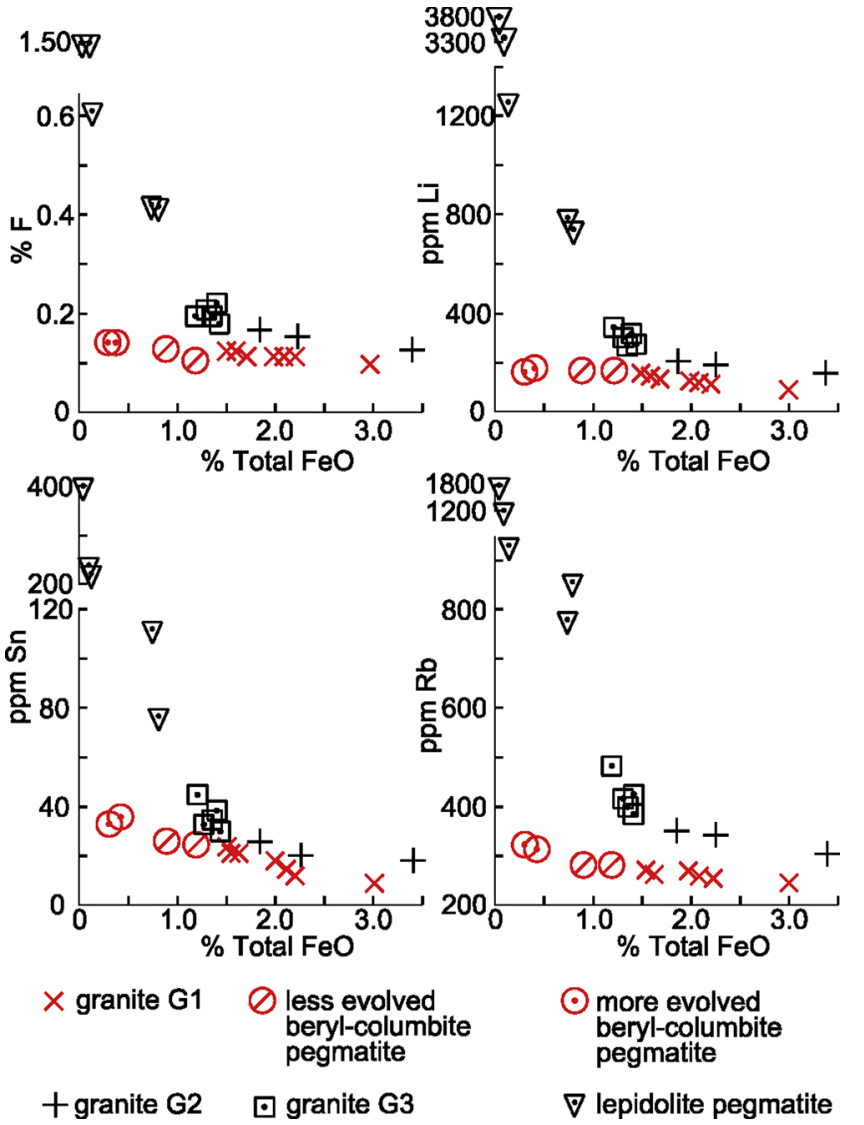

Fig. 4. Variation diagrams of granitic rocks from the Gravanho-Gouveia area, central Portugal define two series: a) granite G1, less evolved beryl-columbite pegmatites and more evolved beryl-columbite pegmatites; b) granites G2 and G3 and lepidolite pegmatites.

Table 5

Representative rare-earth element concentrations ( $\mathrm{ppm}$ ) of granites and granitic aplite-pegmatites from the Gravanho-Gouveia area, central Portugal.

\begin{tabular}{|c|c|c|c|c|c|c|c|}
\hline & \multirow{2}{*}{$\begin{array}{l}\text { Granite } \\
\text { G1 }\end{array}$} & \multirow{2}{*}{$\begin{array}{l}\text { LEBCS } \\
\text { pegmatites }\end{array}$} & \multirow{2}{*}{ MEBCS } & \multicolumn{2}{|c|}{ Granites } & \multicolumn{2}{|c|}{ LS pegmatites } \\
\hline & & & & $\mathrm{G} 2$ & G3 & 13 & 14 \\
\hline $\mathrm{La}$ & 28.40 & 4.12 & 2.16 & 36.00 & 19.45 & 2.46 & 1.50 \\
\hline $\mathrm{Ce}$ & 59.25 & 8.31 & 4.82 & 78.55 & 36.25 & 3.48 & 3.20 \\
\hline $\operatorname{Pr}$ & 7.17 & 1.02 & 0.57 & 9.56 & 4.41 & 0.42 & 0.40 \\
\hline $\mathrm{Nd}$ & 26.35 & 4.08 & 2.00 & 34.00 & 15.52 & 1.67 & 1.32 \\
\hline $\mathrm{Sm}$ & 5.15 & 1.17 & 0.59 & 7.35 & 3.58 & 0.42 & 0.31 \\
\hline $\mathrm{Eu}$ & 0.79 & 0.22 & 0.10 & 0.58 & 0.29 & 0.11 & 0.07 \\
\hline Gd & 4.35 & 0.93 & 0.51 & 6.35 & 3.18 & 0.44 & 0.39 \\
\hline $\mathrm{Tb}$ & 0.68 & 0.14 & 0.09 & 0.98 & 0.54 & 0.07 & 0.06 \\
\hline Dy & 3.38 & 0.65 & 0.49 & 5.16 & 2.72 & 0.29 & 0.26 \\
\hline Ho & 0.62 & 0.07 & 0.06 & 1.02 & 0.51 & $<0.06$ & $<0.06$ \\
\hline $\mathrm{Er}$ & 1.58 & 0.17 & 0.15 & 2.69 & 1.28 & $<0.06$ & $<0.06$ \\
\hline $\mathrm{Tm}$ & 0.25 & $<0.04$ & $<0.04$ & 0.39 & 0.20 & $<0.04$ & $<0.04$ \\
\hline $\mathrm{Yb}$ & 1.76 & 0.18 & 0.17 & 2.50 & 1.25 & $<0.03$ & $<0.04$ \\
\hline $\mathrm{Lu}$ & 0.26 & $<0.02$ & $<0.02$ & 0.40 & 0.18 & $<0.02$ & $<0.02$ \\
\hline
\end{tabular}

LEBCS - less evolved beryl-columbite, MEBCS - more evolved beryl-columbite, LS - lepidolite.

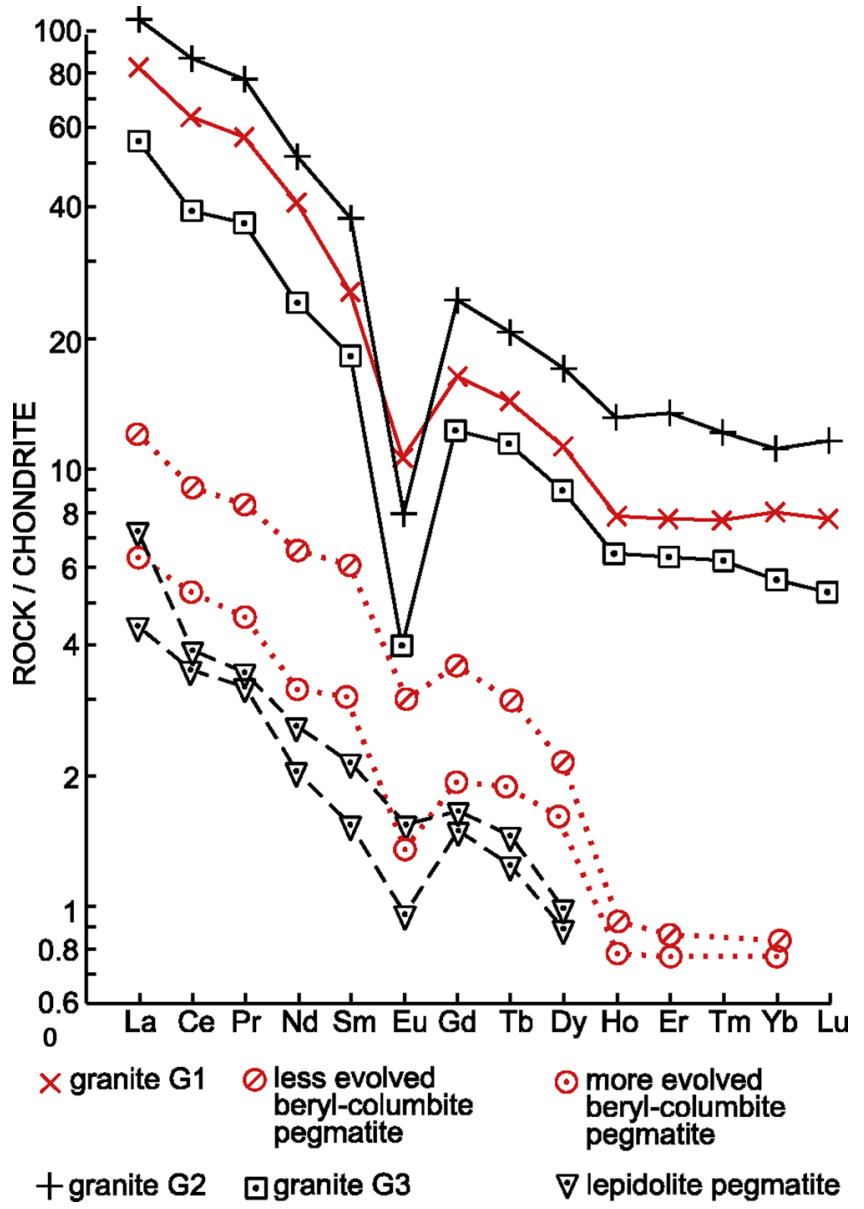

Fig. 5. Chondrite-normalized REE abundances in granitic rocks from the Gravanho-Gouveia area, central Portugal. Granite G1, less evolved beryl-columbite pegmatites and more evolved beryl-columbite pegmatites define subparallel REE patterns. Granites G2 and G3 and lepidolite pegmatites define subparallel REE patterns.

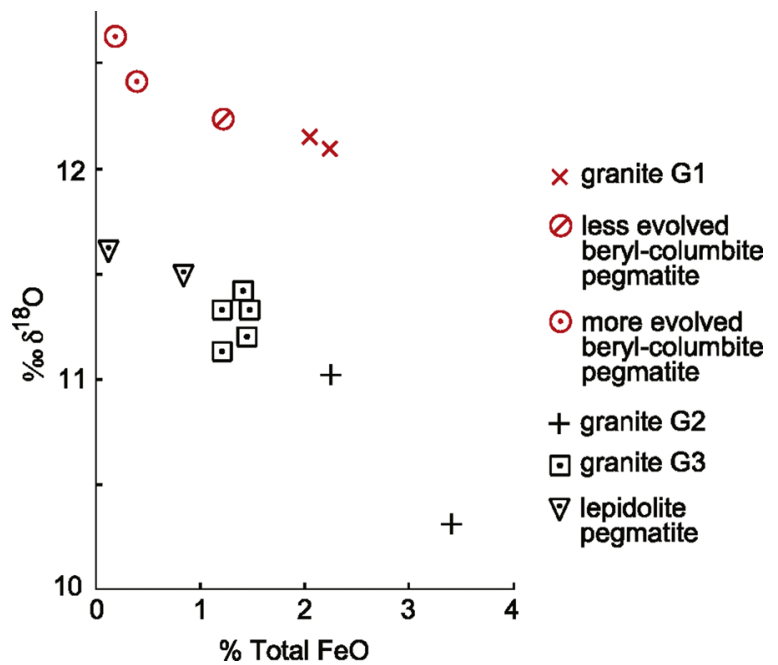

Fig. 6. Diagram of $\delta^{18} \mathrm{O}$ versus total $\mathrm{FeO}$ of granites $\mathrm{G} 1, \mathrm{G} 2$ and $\mathrm{G} 3$ and granitic pegmatites from the Gravanho-Gouveia area, central Portugal, define two distinct trends, one for granite G1, less evolved beryl-columbite pegmatites and more evolved beryl-columbite pegmatites and another for granites G2 and G3 and lepidolite pegmatites. 
Table 6

$\delta^{18} \mathrm{O}$ of selected samples of granites and granitic aplite-pegmatites from the Gravanho-Gouveia area, central Portugal.

\begin{tabular}{ll}
\hline & $\delta^{18} \mathrm{O}$ \\
\hline Granite G1 & 12.1 \\
& 12.1 \\
LEBCS & 12.2 \\
MEBCS & 12.4 \\
pegmatites & 12.6 \\
& \\
Granite G2 & 10.3 \\
& 11.0 \\
Granite G3 & 11.1 \\
& 11.2 \\
& 11.2 \\
& 11.3 \\
LS & 11.4 \\
pegmatites & 11.5 \\
\end{tabular}

LEBCS - less evolved beryl-columbite, MEBCS - more evolved beryl-columbite, LS lepidolite.

\section{Geochemistry of minerals}

\subsection{Feldspars}

Compositions of feldspars from granites and aplite-pegmatites from the Gravanho-Gouveia area are given in Table 7. The anorthite content of plagioclase decreases progressively from the granite G1 to the less and more evolved beryl-columbite pegmatites, and from granite G2 to granite G3 and lepidolite pegmatites. The K-feldspar from these pegmatites tends to have higher orthoclase content and lower $\mathrm{BaO}$ content than the K-feldspar from granite $\mathrm{G} 1$. The $\mathrm{BaO}$ content of K-feldspar phenocrysts from lepidolite pegmatites is lower than those of K-feldspar phenocrysts from granites G2 and G3.

In the three granite types, there is no significant difference in the contents of $\mathrm{P}_{2} \mathrm{O}_{5}$ in feldspar phenocryst and matrix. The $\mathrm{P}_{2} \mathrm{O}_{5}$ content in $\mathrm{K}$-feldspar and plagioclase from pegmatites is higher than in feldspars from the respective granites (Table 8). The $\mathrm{P}_{2} \mathrm{O}_{5}$ content of plagioclase is not related to the anorthite content of plagioclase. The content of $\mathrm{P}_{2} \mathrm{O}_{5}$ in $\mathrm{K}$-feldspar is higher than that of coexisting plagioclase (Table 8), which agrees with the findings of London et al. (1990); Neiva et al. (2008, 2012) and Antunes et al. (2013), for example. The distribution coefficient of $\mathrm{P}$ between $\mathrm{K}$-feldspar and plagioclase pairs (D[P] $\mathrm{Kf} / \mathrm{Pl}$ ) increases from granite G1 to less and more evolved beryl-columbite pegmatites (Table 8),

\subsection{Micas}

The properties from granitic aplite-pegmatites from the Gravanho-
Table 8

Phosphorus content of feldspars from granites and granitic aplite-pegmatites from the Gravanho-Gouveia area, central Portugal.

\begin{tabular}{llllll}
\hline $\mathrm{P}_{2} \mathrm{O}_{5}$ wt.\% & & Mean & Min/Max & $\mathrm{n}$ & D[P]Kf/Pl \\
\hline Granite & $\mathrm{Kf}$ & 0.13 & $0 / 0.27$ & 18 & 1.86 \\
G1 & $\mathrm{Pl}$ & 0.07 & $0 / 0.11$ & 18 & \\
LEBCS & $\mathrm{Kf}$ & 0.44 & $0.36 / 0.59$ & 13 & 1.91 \\
pegmatite & $\mathrm{Pl}$ & 0.23 & $0.10 / 0.44$ & 12 & \\
MEBCS & $\mathrm{Kf}$ & 1.33 & $0.88 / 1.68$ & 18 & 2.33 \\
pegmatite & $\mathrm{Pl}$ & 0.57 & $0.14 / 0.73$ & 15 & \\
Granite & $\mathrm{Kf}$ & 0.12 & $0 / 0.20$ & 18 & 1.50 \\
G2 & $\mathrm{Pl}$ & 0.08 & $0 / 0.12$ & 19 & \\
Granite & $\mathrm{Kf}$ & 0.19 & $0 / 0.35$ & 10 & 1.58 \\
G3 & $\mathrm{Pl}$ & 0.12 & $0 / 0.21$ & 19 & \\
LS & $\mathrm{Kf}$ & 0.35 & $0.01 / 0.55$ & 21 & 1.46 \\
pegmatite & $\mathrm{Pl}$ & 0.24 & $0 / 0.36$ & 31 & \\
\hline
\end{tabular}

LEBCS - less evolved beryl-columbite, MEBCS - more evolved beryl-columbite, LS - lepidolite.

Gouveia area are shown in Table 2. The chemical compositions of micas from granites and granitic aplite-pegmatites from the Gravanho-Gouveia area are given in Table 9. The formulae were recalculated to $22^{+}$. cation charges to be plotted in the diagram of Tischendorf et al. (2004) (Fig. 7a). Granite samples of G1, G2 and G3 and less and more evolved beryl-columbite pegmatites contain magmatic muscovite (Fig. 7b). Lepidolite pegmatites contain magmatic muscovite, Li-mica apparently ranging from zinnwaldite to lepidolite (ca. 0.9 to $1.8 \mathrm{apfu} \mathrm{Li}$, Table 9) and late nearly stoichiometric muscovite (Fig. 7b).

Magmatic muscovites from granite G1 and the less and more evolved beryl-columbite pegmatites have progressively higher contents of $\mathrm{Al}^{\mathrm{VI}}, \mathrm{Li}, \mathrm{Na}$ and $\mathrm{F}$ and lower contents of $\mathrm{Ti}, \mathrm{Fe}^{2+}$ and $\mathrm{Mg}$ (Table 9). These muscovites delineate a trend in the $\mathrm{Al}^{\mathrm{VI}}$ versus $\mathrm{Fe}^{2+}$ diagram (Fig. 8). Similarly, the contents of $\mathrm{Si}, \mathrm{Al}^{\mathrm{VI}}$, $\mathrm{Li}$ and $\mathrm{F}$ increase progressively and $\mathrm{Ti}, \mathrm{Fe}^{2+}, \mathrm{Mg}$ and $\mathrm{OH}$ contents decrease progressively, going from the magmatic muscovite of the granite G2 to muscovites from granite G3 and lepidolite pegmatites (Table 9). The trend established with these muscovites is parallel and close to the trend defined by muscovites of granite G1 and beryl-columbite pegmatites (Fig. 8). The late muscovite that partially surrounds trilithionite (Fig. 3d) contains more $\mathrm{Al}^{\mathrm{VI}}$ and $\mathrm{K}$ and less $\mathrm{Si}, \mathrm{Ti}, \mathrm{Fe}^{2+}, \mathrm{Mn}, \mathrm{Mg}, \mathrm{Li}, \mathrm{Na}$ and $\mathrm{F}$ than the magmatic muscovite of lepidolite pegmatites (Table 9).

\subsection{Other silicate minerals}

The composition of topaz from lepidolite aplite-pegmatites from the Gravanho-Gouveia area is given in Table 10. It contains 18.9 wt.\% F which is in the range of topaz from the S-type and A-type granites in the Krušné Hory/Erzgebirge (17.9-19.8 wt.\% F) (Breiter et al., 2013) and more than in topaz from lepidolite aplite-pegmatite sills (5.7 wt.\% F) from the Guarda-Belmonte area, in central Portugal (Neiva and Ramos, 2010).

Table 7

Compositions of feldspars from granites and granitic aplite-pegmatites from the Gravanho-Gouveia area, central Portugal.

\begin{tabular}{|c|c|c|c|c|c|c|c|}
\hline & & $\begin{array}{l}\text { Granite } \\
\text { G1 }\end{array}$ & $\begin{array}{l}\text { LEBCS } \\
\text { pegmatites }\end{array}$ & $\begin{array}{l}\text { MEBCS } \\
\text { pegmatites }\end{array}$ & $\begin{array}{l}\text { Granite } \\
\text { G2 }\end{array}$ & $\begin{array}{l}\text { Granite } \\
\text { G3 }\end{array}$ & $\begin{array}{l}\text { LS } \\
\text { pegmatites }\end{array}$ \\
\hline \multirow[t]{2}{*}{ Anorthite content of plagioclase } & Phenocryst & $5-30$ & - & - & $18-29$ & $1-16$ & - \\
\hline & Matrix & $2-24$ & $3-8$ & $0-2$ & $1-16$ & $0-11$ & $0-2$ \\
\hline \multirow[t]{2}{*}{ Orthoclase content of K-feldspar } & Phenocryst & $90-94$ & - & - & $90-100$ & $93-100$ & - \\
\hline & Matrix & $88-97$ & $91-98$ & $95-97$ & $87-100$ & $94-100$ & $94-98$ \\
\hline \multirow[t]{2}{*}{ wt. $\% \mathrm{BaO}$ of $\mathrm{K}$-feldspar } & Phenocryst & $\leq 0.06-0.29$ & - & - & $\leq 0.06-0.18$ & $\leq 0.06-0.08$ & - \\
\hline & Matrix & $\leq 0.06-0.14$ & $\leq 0.06$ & $\leq 0.06$ & $\leq 0.06$ & $\leq 0.06$ & $\leq 0.06$ \\
\hline
\end{tabular}

LEBCS - less evolved beryl-columbite, MEBCS - more evolved beryl-columbite; LS - lepidolite; — not found. 
Table 9

Representative chemical analyses in wt.\% of primary micas and a late muscovite from granites and aplite-pegmatites from the Gravanho-Gouveia area, central Portugal.

\begin{tabular}{|c|c|c|c|c|c|c|c|c|c|c|}
\hline \multirow[t]{3}{*}{ wt.\% } & \multirow{3}{*}{$\begin{array}{l}\text { Granite } \\
\text { G1 } \\
\mathrm{Mu}\end{array}$} & \multirow{2}{*}{\multicolumn{2}{|c|}{$\begin{array}{l}\text { LEBCS } \\
\text { pegmatites }\end{array}$}} & \multicolumn{2}{|l|}{ Granites } & \multicolumn{5}{|l|}{ LS } \\
\hline & & & & \multirow{2}{*}{$\begin{array}{l}\mathrm{G} 2 \\
\mathrm{Mu}\end{array}$} & \multirow{2}{*}{$\begin{array}{l}\mathrm{G} 3 \\
\mathrm{Mu}\end{array}$} & \multicolumn{5}{|c|}{ pegmatites } \\
\hline & & $\mathrm{Mu}$ & $\mathrm{Mu}$ & & & $\mathrm{Mu}$ & Zin & $\mathrm{Tri}^{+}$ & $\mathrm{Pol}^{+}$ & Late $\mathrm{Mu}$ \\
\hline $\mathrm{SiO}_{2}$ & 46.84 & 47.43 & 46.66 & 46.31 & 46.48 & 47.06 & 45.36 & 51.61 & 57.48 & 45.90 \\
\hline $\mathrm{TiO}_{2}$ & 0.61 & - & - & 1.01 & 0.51 & 0.10 & 0.61 & 0.04 & 0.04 & - \\
\hline $\mathrm{Al}_{2} \mathrm{O}_{3}$ & 35.30 & 35.15 & 36.61 & 34.20 & 34.80 & 35.51 & 23.52 & 25.52 & 17.92 & 37.70 \\
\hline $\mathrm{FeO}$ & 1.24 & 0.79 & 0.38 & 2.10 & 1.70 & 1.20 & 9.66 & 0.18 & 0.18 & 0.08 \\
\hline $\mathrm{MnO}$ & - & 0.02 & 0.01 & - & - & 0.25 & 0.25 & 1.24 & 0.48 & 0.09 \\
\hline $\mathrm{MgO}$ & 0.51 & 0.08 & 0.09 & 0.95 & 0.59 & 0.11 & 2.09 & - & 0.02 & - \\
\hline $\mathrm{Li}_{2} \mathrm{O}^{*}$ & 0.07 & 0.10 & 0.14 & 0.34 & 0.38 & 0.45 & 3.45 & 5.26 & 6.95 & 0.06 \\
\hline $\mathrm{CaO}$ & 0.03 & 0.03 & 0.01 & 0.03 & 0.08 & 0.01 & 0.03 & 0.02 & 0.02 & - \\
\hline $\mathrm{Na}_{2} \mathrm{O}$ & 0.02 & 0.14 & 0.33 & - & 0.02 & 0.37 & 0.13 & 0.22 & - & 0.05 \\
\hline $\mathrm{K}_{2} \mathrm{O}$ & 10.90 & 11.32 & 10.96 & 10.80 & 10.55 & 10.35 & 10.42 & 10.50 & 10.68 & 11.09 \\
\hline $\mathrm{Cl}$ & - & - & - & - & - & - & - & - & 0.01 & 0.01 \\
\hline $\mathrm{F}$ & 0.26 & 0.35 & 0.45 & 0.90 & 0.98 & 1.10 & 2.80 & 7.13 & 9.22 & 0.24 \\
\hline \multirow[t]{2}{*}{$\mathrm{H}_{2} \mathrm{O}^{*}$} & 4.40 & 4.34 & 4.31 & 4.08 & 4.04 & 4.01 & 2.99 & 1.18 & 0.21 & 4.41 \\
\hline & 100.18 & 99.75 & 99.95 & 100.72 & 100.13 & 100.52 & 101.31 & 103.20 & 103.71 & 99.63 \\
\hline $\mathrm{O} \equiv \mathrm{F}$ & 0.11 & 0.15 & 0.19 & 0.38 & 0.41 & 0.46 & 1.18 & 2.99 & 3.87 & 0.10 \\
\hline Total & 100.07 & 99.60 & 99.76 & 100.34 & 99.72 & 100.06 & 100.13 & 100.21 & 99.84 & 99.53 \\
\hline $\mathrm{Si}$ & 3.105 & 3.155 & 3.090 & 3.080 & 3.096 & 3.113 & 3.151 & 3.395 & 3.758 & 3.045 \\
\hline $\mathrm{Al}^{\mathrm{IV}}$ & 0.895 & 0.845 & 0.910 & 0.920 & 0.904 & 0.887 & 0.849 & 0.605 & 0.242 & 0.955 \\
\hline$\Sigma \mathrm{T}$ & 4.00 & 4.00 & 4.00 & 4.00 & 4.00 & 4.00 & 4.00 & 4.00 & 4.00 & 4.00 \\
\hline $\mathrm{Al}^{\mathrm{VI}}$ & 1.863 & 1.910 & 1.948 & 1.761 & 1.827 & 1.881 & 1.076 & 1.374 & 1.139 & 1.992 \\
\hline $\mathrm{Ti}$ & 0.030 & - & - & 0.051 & 0.026 & 0.005 & 0.032 & 0.002 & 0.002 & - \\
\hline $\mathrm{Fe}^{2+}$ & 0.069 & 0.044 & 0.021 & 0.117 & 0.095 & 0.066 & 0.561 & 0.010 & 0.010 & 0.004 \\
\hline $\mathrm{Mn}$ & - & 0.001 & 0.001 & - & - & 0.014 & 0.015 & 0.069 & 0.027 & 0.005 \\
\hline $\mathrm{Mg}$ & 0.050 & 0.008 & 0.009 & 0.094 & 0.059 & 0.011 & 0.216 & - & 0.002 & - \\
\hline $\mathrm{Li}$ & 0.018 & 0.026 & 0.036 & 0.092 & 0.103 & 0.119 & 0.964 & 1.391 & 1.828 & 0.016 \\
\hline$\Sigma$ & 2.03 & 1.99 & 2.02 & 2.12 & 2.11 & 2.10 & 2.86 & 2.85 & 3.01 & 2.02 \\
\hline $\mathrm{Ca}$ & 0.002 & 0.002 & 0.001 & 0.002 & 0.006 & 0.001 & 0.002 & 0.001 & 0.001 & - \\
\hline $\mathrm{Na}$ & 0.003 & 0.018 & 0.042 & - & 0.003 & 0.047 & 0.018 & 0.028 & - & 0.006 \\
\hline $\mathrm{K}$ & 0.922 & 0.961 & 0.926 & 0.916 & 0.896 & 0.873 & 0.923 & 0.881 & 0.891 & 0.938 \\
\hline$\Sigma$ & 0.93 & 0.98 & 0.97 & 0.92 & 0.91 & 0.92 & 0.94 & 0.92 & 0.91 & 0.94 \\
\hline $\mathrm{Cl}$ & - & - & - & - & - & - & - & - & 0.001 & - \\
\hline $\mathrm{F}$ & 0.055 & 0.074 & 0.094 & 0.189 & 0.206 & 0.230 & 0.615 & 1.484 & 1.907 & 0.050 \\
\hline $\mathrm{OH}^{*}$ & 1.945 & 1.926 & 1.906 & 1.811 & 1.794 & 1.770 & 1.385 & 0.516 & 0.092 & 1.950 \\
\hline
\end{tabular}

LEBCS - less evolved beryl-columbite, MEBCS - more evolved beryl-columbite, LS - lepidolite; Mu - muscovite, Zin - zinnwaldite, Tri - trilithionite, Pol - polylithionite; trilithionite and polylithionite correspond to the lepidolite series; - below the detection limit; $\mathrm{Tri}^{+}{ }^{+}$contains $\mathrm{Rb}_{2} \mathrm{O} 0.30$ and 0.013 pfu of $\mathrm{Rb}$; $\mathrm{Pol}{ }^{+}$contains 0.50 wt. $\% \mathrm{Rb}_{2} \mathrm{O}$ and $0.021 \mathrm{pfu}$ of $\mathrm{Rb} ; \mathrm{Li}_{2} \mathrm{O} *$ values calculated from the equations of Tischendorff et al. (1997); $\mathrm{OH}^{*}$ calculated by difference to $2.000 ; \mathrm{H}_{2} \mathrm{O} *$ calculated by stoichiometry. Number of ions on the basis of $12(\mathrm{O}, \mathrm{OH}, \mathrm{F})$.

Selected compositions of tourmaline from granitic aplite-pegmatites from the Gravanho-Gouveia area are given in Table 10. Unzoned tourmaline crystals occur in beryl-columbite pegmatites and lepidolite pegmatites, but zoned crystals only occur in the former pegmatites. Compositions of unzoned crystals and rims of zoned crystals belong to the $\mathrm{Na}(+\mathrm{K})$ group, whereas the cores of zoned crystals belong to the vacancy group (Fig. 9a, b). The former are schorl and the latter are foitite compositions (Fig. 9c). The change in composition from foitite core to schorl rim defines a discontinuous chemical zoning with a decrease in ${ }^{\mathrm{Y}} \mathrm{Mg} /{ }^{\mathrm{Y}}\left(\mathrm{Mg}+\mathrm{Fe}^{2+}\right), \mathrm{X}$-vacancy/(Na $+\mathrm{X}$-vacancy) and an increase in ${ }^{\mathrm{Y}} \mathrm{Fe}^{2+}, \mathrm{Na}$ and $\mathrm{F}$ contents (Fig. 9d, e, Table 10), probably formed during closed-system growth. This also occurs in some zoned magmatic tourmaline crystals from granitic pegmatites from JalesGralheira, in northern Portugal (Neiva et al., 2007). Schorl from lepidolite pegmatites has higher $\mathrm{Ti}, \mathrm{Ca}$ and $\mathrm{F}$ contents and lower ${ }^{\mathrm{Y}} \mathrm{Al}$ content than schorl from beryl-columbite pegmatites and plots outside the trends defined by the core and rim of zoned crystals from beryl-columbite pegmatites (Table 10, Fig. 9).

In the Gravanho-Gouveia area, beryl crystals occur in more evolved beryl-columbite pegmatites (Table 10). The contents of $\mathrm{Ti}, \mathrm{Mn}, \mathrm{Mg}, \mathrm{Ca}$ and $\mathrm{K}$ are low. Lithium substitutes for Be in the tetrahedral site with the charge balance by alkali ions of suitable radii into the channels (Aurisicchio et al., 1988), particularly $\mathrm{Na}^{+}$and $\mathrm{Cs}^{+}$(Hawthorne and Huminicki, 2002; Černý et al., 2003; Neiva and Neiva, 2005).

\subsection{Oxide minerals}

Some chemical analyses of cassiterite from lepidolite pegmatites of the Gravanho-Gouveia area are given in Table 11. Some crystals have slightly more $\mathrm{Nb}$ than $\mathrm{Ta}$, whereas others have more $\mathrm{Ta}$ than $\mathrm{Nb}$ (Fig. 10a), as in cassiterite from the tin-enriched granitic pegmatites from northern Portugal (Neiva, 1996). In zoned crystals, the lighter zone in backscattered images has higher contents of $\mathrm{Ta}, \mathrm{Nb}$ and $\mathrm{Mn}$ and lower content of Sn than the darker zone (Fig. 10a, Table 11). The unzoned crystals and the lighter zone of other crystals have higher Mn content than Fe content (Table 11), which is unusual, but also occurs in cassiterite crystals from lepidolite aplite-pegmatite veins from Segura, central Portugal (Antunes et al., 2013). The compositions of cassiterite plot close to the trend defined by the ideal columbite substitution $(\mathrm{Fe}, \mathrm{Mn})^{2+}+2(\mathrm{Nb}, \mathrm{Ta})^{5+} \leftrightarrows 3(\mathrm{Sn}, \mathrm{Ti})^{4+}$ (Černý et al., 1985b) (Fig. 10c).

Rutile from lepidolite pegmatites occurs as homogeneous or heterogeneous grains (Fig. 10d, Table 11): the latter have a lighter zone with higher $\mathrm{Nb}$ and $\mathrm{Fe}^{2+}$ contents, similar to higher Ta content and lower Ti content than the darker zone. The lighter zone contains up to 3.4 wt.\% FeO, 10.9 wt. $\% \mathrm{Ta}_{2} \mathrm{O}_{5}$ and $5.5 \mathrm{wt} . \% \mathrm{Nb}_{2} \mathrm{O}_{5}$. There is a progressive increase in $\mathrm{Nb}+\mathrm{Ta}$ and a progressive decrease in $\mathrm{Sn}+\mathrm{Ti}+\mathrm{W}$ from the homogeneous grains to the darker zone and lighter zone of heterogeneous grains (Fig. 10d). The rutile compositions plot close to 


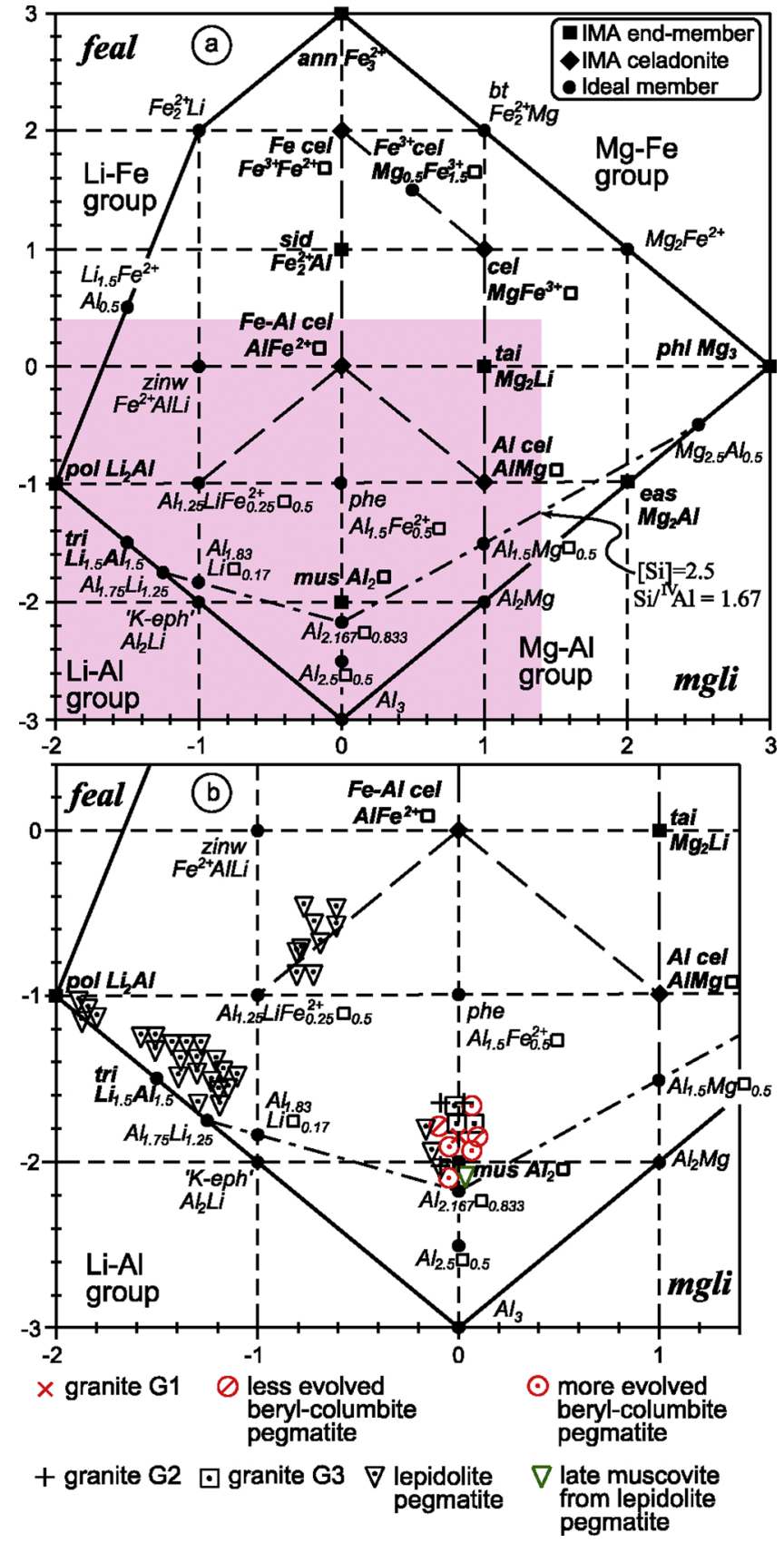

Fig. 7. Plots of micas from granites and granitic pegmatites from the GravanhoGouveia area, central Portugal, on the diagram for potassium micas of Tischendorf et al. (2004). a. the diagram of feal $\left(\mathrm{Fe}+\mathrm{Mn}+\mathrm{Ti}-\mathrm{Al}^{\mathrm{VI}}\right)$ vs. mgli (Mg-Li) of Tischendorf et al. showing the area of the diagram b. Al cel - aluminoceladonite, ann - annite, bt - biotite, cel - celadonite, eas - eastonite, Fe-Al cel - ferro-aluminoceladonite, $\mathrm{Fe}$ cel - ferroceladonite, $\mathrm{Fe}^{3+}$ cel - ferriceladonite, K-eph - K-ephesite, mus - muscovite, phe - phengite, phl - phlogopite, pol - polylithionite, sid - siderophyllite, tai - tainiolite, tri - trilithionite, zinw zinnwaldite. b. Compositions of analysed micas from the Gravanho-Gouveia area.

the $(\mathrm{Fe}, \mathrm{Mn})(\mathrm{Nb}, \mathrm{Ta})_{2}$ join.

\section{Discussion}

Based on the geochemistry of major and trace elements, REE, Sr and $\mathrm{Sm}-\mathrm{Nd}$ isotopic data, $\delta^{18} \mathrm{O}$ values of granites and the geochemistry of their minerals, the biotite $>$ muscovite granite G1 and muscovite >

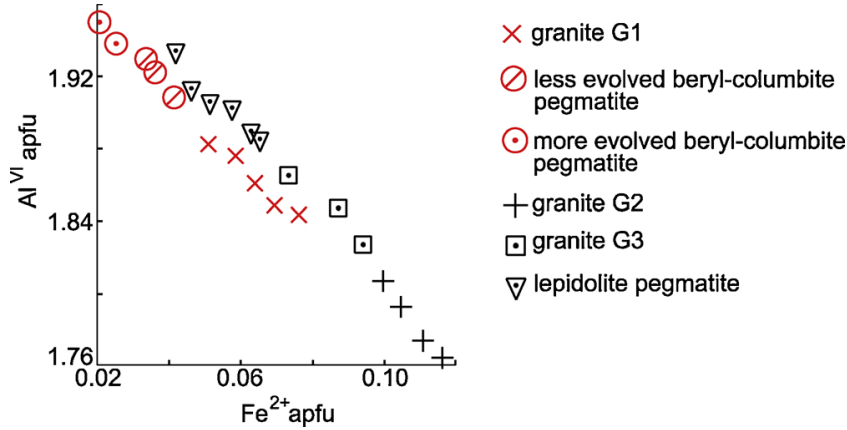

Fig. 8. The $\mathrm{Al}^{\mathrm{VI}}$ vs. $\mathrm{Fe}^{2+}$ diagram of magmatic muscovites from granites and granitic pegmatites from the Gravanho-Gouveia area, central Portugal. Two close distinct trends, one for muscovites from granite G1, less evolved berylcolumbite pegmatites and more evolved beryl-columbite pegmatites and another for muscovites from granites G2 and G3 and lepidolite pegmatites.

biotite granodiorite to granite G2 correspond to two distinct pulses of granite magma derived by partial melting of mid-crustal metasediments, mainly metapelite and some metagraywacke (Neiva et al., 2009). The muscovite > biotite granite G3 is derived from the granodiorite magma G2 by the fractional crystallization of plagioclase, biotite, quartz and ilmenite (Neiva et al., 2009).

The less and more evolved beryl-columbite pegmatites are paragenetically similar. These pegmatites show a gradational transition to the host granite G1 (Fig. 2); variation diagrams for oxides and trace elements (Fig. 4) and the subparallel REE patterns (Fig. 5) suggest that they constitute a single evolutionary series. This trend is further corroborated with the $\delta^{18} \mathrm{O}$ versus total $\mathrm{FeO}$ diagram (Fig. 6). Granites G2 and G3 and the lepidolite pegmatites define another fractionation trend, which suggests a series distinct from that for the host granite G1 and associated pegmatites (Fig. 4). The subparallel REE patterns and the $\delta^{18} \mathrm{O}$ versus total $\mathrm{FeO}$ diagram also support the two distinct series (Figs. 5 and 6). The decrease in HREE in each series is due to zircon fractionation (e.g. Mittlefehldt and Miller, 1983), as the Zr content decreases in each series (Table 4). The decreases in MREE and LREE are attributed to fractionation of apatite and monazite, respectively (Bea, 1996). The whole-rock $\mathrm{Zr}, \mathrm{P}_{2} \mathrm{O}_{5}$, La and Ce contents (Tables 4 and 5) are consistent with zircon and monazite saturations and appropriate fractionation of zircon, apatite and monazite. There is an increase in $\delta^{18} \mathrm{O}$ from granite $\mathrm{G} 1$ to more evolved beryl-columbite pegmatites by up to $0.4 \%$, and up to $0.9 \%$ from granite G2 to lepidolite pegmatites (Table 6), which is compatible with fractional crystallization processes (e.g., White, 2003). In each series, the anorthite content of plagioclase and $\mathrm{BaO}$ content of $\mathrm{K}$-feldspar phenocrysts decrease (Table 7). The $\mathrm{P}_{2} \mathrm{O}_{5}$ contents of K-feldspar and plagioclase of pegmatites are higher than those of feldspars from granites of the respective series (Table 8). Muscovite from each series defines a trend in the $\mathrm{Al}^{\mathrm{VI}}$ versus $\mathrm{Fe}^{2+}$ diagram (Fig. 8). The occurrence of topaz and Li-F-rich micas in the lepidolite pegmatites suggest increase of the activity of $F$ in this rock. In the lepidolite pegmatites, the homogeneous crystals of rutile are interpreted as magmatic, whereas the heterogeneous crystals have higher contents of $\mathrm{Ta}, \mathrm{Nb}$ and $\mathrm{Fe}^{2+}$ than the homogeneous crystals (Table 11) and are derived from hydrothermal fluids.

The least-squares regression method was used to try to model the evolution of major elements for each series. However, it was impossible to get good results for any series and consequently trace elements cannot be modelled taking into account their evolution. Secondary muscovite replacing mainly plagioclase and hydrothermal columbitegroup minerals in all pegmatites (Neiva et al., 2015), the occurrence of chlorite in beryl-columbite pegmatites and some late muscovite surrounding trilithionite, and the heterogenous crystals of rutile in lepidolite pegmatites (Fig. 3d, Table 9; Fig. 3f, Table 11, Fig. 10d) are 
Table 10

Representative chemical analyses in wt.\% of some silicate minerals from granitic aplite-pegmatites from the Gravanho-Gouveia area, central Portugal.

\begin{tabular}{|c|c|c|c|c|c|c|c|c|}
\hline & \multirow{4}{*}{$\begin{array}{l}\text { Topaz } \\
\text { LS pegmatite }\end{array}$} & \multicolumn{4}{|c|}{ Tourmaline } & & & \multirow{4}{*}{$\begin{array}{l}\text { Beryl } \\
\text { MEBCS pegmatite }\end{array}$} \\
\hline & & & BCS pegmatites & & & LS pegmatite & & \\
\hline & & & \multirow[t]{2}{*}{ Unzoned crystal } & \multicolumn{2}{|c|}{ Zoned crystals } & \multirow[t]{2}{*}{ Unzoned crystal } & & \\
\hline & & & & Core & Rim & & & \\
\hline $\mathrm{SiO}_{2}$ & 32.10 & $\mathrm{SiO}_{2}$ & 35.75 & 36.00 & 34.51 & 35.60 & $\mathrm{SiO}_{2}$ & 66.60 \\
\hline $\mathrm{Al}_{2} \mathrm{O}_{3}$ & 56.13 & $\mathrm{TiO}_{2}$ & 0.43 & 0.21 & 0.27 & 0.86 & $\mathrm{Al}_{2} \mathrm{O}_{3}$ & 18.50 \\
\hline $\mathrm{MnO}$ & 0.03 & $\mathrm{~B}_{2} \mathrm{O}_{3} *$ & 10.44 & 10.62 & 10.32 & 10.44 & $\mathrm{FeO}$ & 0.24 \\
\hline $\mathrm{F}$ & 18.91 & $\mathrm{Al}_{2} \mathrm{O}_{3}$ & 33.22 & 34.82 & 34.95 & 32.48 & $\mathrm{MnO}$ & 0.01 \\
\hline $\mathrm{H}_{2} \mathrm{O}$ & 0.84 & $\mathrm{FeO}$ & 12.27 & 9.45 & 13.23 & 12.00 & $\mathrm{MgO}$ & 0.01 \\
\hline Sum & 108.01 & $\mathrm{MnO}$ & 0.08 & 0.01 & 0.17 & - & $\mathrm{TiO}_{2}$ & 0.01 \\
\hline $\mathrm{O} \equiv \mathrm{F}$ & 7.94 & $\mathrm{MgO}$ & 2.13 & 2.98 & 0.83 & 2.35 & $\mathrm{CaO}$ & 0.01 \\
\hline Total & 100.07 & $\mathrm{CaO}$ & 0.07 & 0.02 & 0.03 & 0.44 & $\mathrm{BeO}$ & 13.60 \\
\hline $\mathrm{Si}$ & 3.928 & $\mathrm{Li}_{2} \mathrm{O}^{* * *}$ & 0.58 & 0.92 & 0.02 & 0.70 & $\mathrm{Li}_{2} \mathrm{O}$ & 0.07 \\
\hline $\mathrm{Al}$ & 0.072 & $\mathrm{Na}_{2} \mathrm{O}$ & 1.63 & 1.52 & 1.86 & 1.72 & $\mathrm{Na}_{2} \mathrm{O}$ & 0.23 \\
\hline$\Sigma$ & 4.00 & $\mathrm{~K} 2 \mathrm{O}$ & 0.05 & 0.04 & 0.02 & - & $\mathrm{K} 2 \mathrm{O}$ & 0.01 \\
\hline $\mathrm{Al}$ & 8.022 & $\mathrm{H}_{2} \mathrm{O}^{*}$ & 3.41 & 3.56 & 3.32 & 3.32 & $\mathrm{Rb}_{2} \mathrm{O}$ & - \\
\hline Mn & 0.003 & $\mathrm{~F}$ & 0.40 & 0.22 & 0.52 & 0.59 & $\mathrm{Cs}_{2} \mathrm{O}$ & 0.07 \\
\hline$\Sigma$ & 8.03 & $\mathrm{Cl}$ & - & - & - & - & $\mathrm{H}_{2} \mathrm{O}^{+}$ & 0.51 \\
\hline $\mathrm{F}$ & 7.317 & Sum & 100.46 & 100.37 & 100.05 & 100.50 & Total & 99.87 \\
\hline $\mathrm{OH}$ & 0.685 & $\mathrm{OF} \equiv \mathrm{F}$ & 0.17 & 0.09 & 0.22 & 0.25 & & \\
\hline \multirow[t]{20}{*}{$\Sigma$} & 8.00 & Total & 100.29 & 100.28 & 99.83 & 100.25 & $\mathrm{Si}$ & 6.000 \\
\hline & & $\mathrm{T} \mathrm{Si}$ & 5.949 & 5.896 & 5.809 & 5.932 & $\mathrm{Be}$ & 2.952 \\
\hline & & $\mathrm{Al}$ & 0.051 & 0.104 & 0.191 & 0.068 & $\mathrm{Li}$ & 0.025 \\
\hline & & B & 3.000 & 3.000 & 3.000 & 3.000 & $\mathrm{Si}$ & 0.018 \\
\hline & & $\mathrm{Z} \mathrm{Al}$ & 6.000 & 6.000 & 6.000 & 6.000 & $\mathrm{Al}$ & - \\
\hline & & Y Al & 0.464 & 0.616 & 0.743 & 0.311 & $\Sigma$ & 3.00 \\
\hline & & $\mathrm{Ti}$ & 0.054 & 0.026 & 0.034 & 0.108 & $\mathrm{Al}$ & 1.970 \\
\hline & & $\mathrm{Mg}$ & 0.529 & 0.727 & 0.208 & 0.584 & $\mathrm{Fe}^{2+}$ & 0.018 \\
\hline & & $\mathrm{Mn}$ & 0.011 & 0.001 & 0.024 & - & $\mathrm{Mn}$ & 0.001 \\
\hline & & $\mathrm{Fe}^{2+}$ & 1.708 & 1.294 & 1.863 & 1.672 & $\mathrm{Mg}$ & 0.001 \\
\hline & & $\mathrm{Li}$ & 0.388 & 0.606 & 0.014 & 0.469 & $\Sigma$ & 1.99 \\
\hline & & $\Sigma \mathrm{Y}$ & 3.15 & 3.27 & 2.89 & 3.14 & $\mathrm{Ca}$ & 0.001 \\
\hline & & $\mathrm{X} \mathrm{Ca}$ & 0.012 & 0.004 & 0.005 & 0.078 & $\mathrm{Na}$ & 0.040 \\
\hline & & $\mathrm{Na}$ & 0.526 & 0.482 & 0.607 & 0.557 & $\mathrm{~K}$ & 0.001 \\
\hline & & $\mathrm{K}$ & 0.010 & 0.008 & 0.004 & - & $\mathrm{Rb}$ & - \\
\hline & & $\square$ & 0.452 & 0.506 & 0.384 & 0.365 & Cs & 0.002 \\
\hline & & $\mathrm{OH}^{*}$ & 3.789 & 3.886 & 3.723 & 3.690 & $\Sigma$ & 0.04 \\
\hline & & $\mathrm{F}$ & 0.211 & 0.114 & 0.277 & 0.310 & $\mathrm{H}_{2} \mathrm{O}$ & 0.307 \\
\hline & & $\mathrm{Cl}$ & - & - & - & - & & \\
\hline & & Name & Schorl & Foitite & Schorl & Schorl & & \\
\hline
\end{tabular}

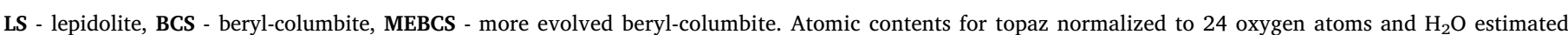

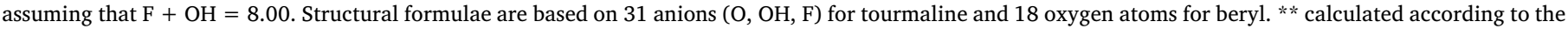

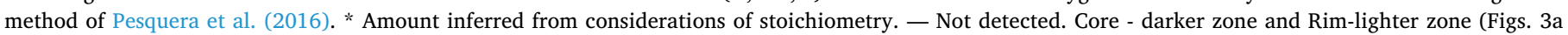
and 9).

findings that suggest that they present some metasomatic effects due to hydrothermal fluids and can explain why it is difficult to model major elements.

The hydrothermal alteration of granites, particularly pegmatites, documents the presence of hydrothermal fluids, which certainly affected most of the granitic rocks studied. However, based on variations in the major and trace elements of apparently unaltered granitic rocks and variations in their mineral compositions, it is possible to conclude that aplite-pegmatites from the Gravanho-Gouveia area are derived from their parent granite magma in each series by fractional crystallization of quartz, plagioclase, K-feldspar, biotite and ilmenite.

The more evolved beryl-columbite pegmatites were hydrothermally altered into episyenite, with gains in $\mathrm{Al}_{2} \mathrm{O}_{3}, \mathrm{~K}_{2} \mathrm{O}$ and $\mathrm{Rb}$ (Table 4) due to microclinization and elevated $\mathrm{F}$ and $\mathrm{Sn}$ contents attributed to some fluorite and cassiterite, respectively, and loss of $\mathrm{SiO}_{2}$ due to a decrease in quartz and $\mathrm{Nb}$ and $\mathrm{Zn}$ contents, which is attributed to the alteration of muscovite.

\section{Conclusions}

Field observations together with the petrography, mineralogy and geochemistry of granites and associated aplite-pegmatite dykes and sills in the Gravanho-Gouveia area indicate the presence of two series of granitic rocks. In each series, pegmatites evolved via the fractional crystallization of quartz, plagioclase, K-feldspar, biotite and ilmenite from the respective parent granitic magma. Cassiterite occurs in lepidolite pegmatites.

Chemically distinct hydrothermal fluids caused the crystallization of a second generation of columbite-tantalite in all pegmatites (Neiva et al., 2015). Another hydrothermal fluid caused the crystallization of secondary muscovite and chlorite in the beryl-columbite pegmatites. Other hydrothermal fluids caused the crystallization of a late muscovite and heterogeneous zoned crystals of rutile in the lepidolite pegmatites.

The most hydrothermally altered rocks are episyenites, which are reddish in colour. The major and trace elements of hydrothermally altered rocks suggest that they are derived from the hydrothermal alteration of a more evolved beryl-columbite pegmatite due to regional circulation of fluids in the granitic rocks. 

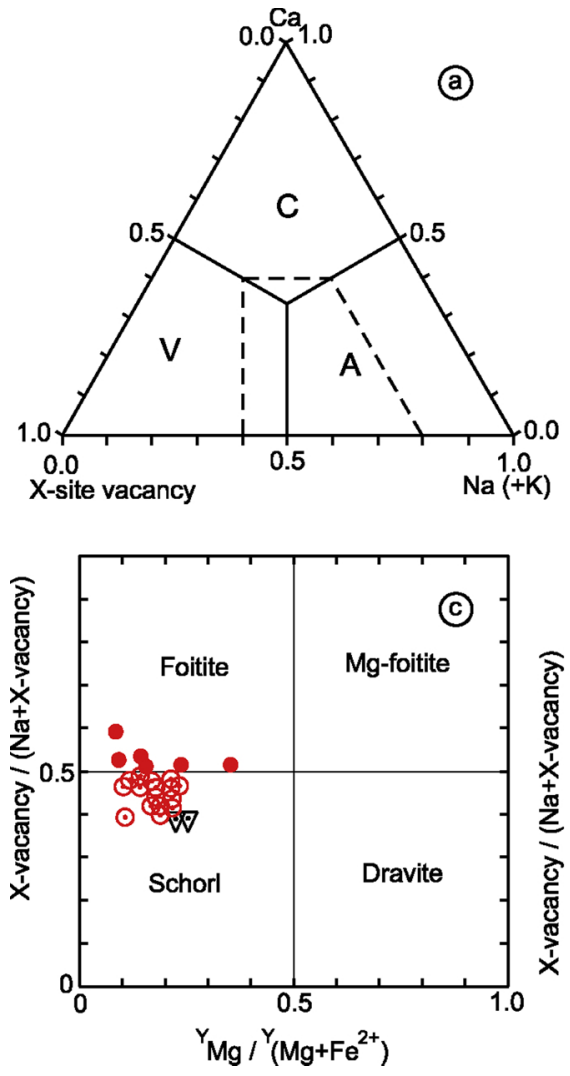
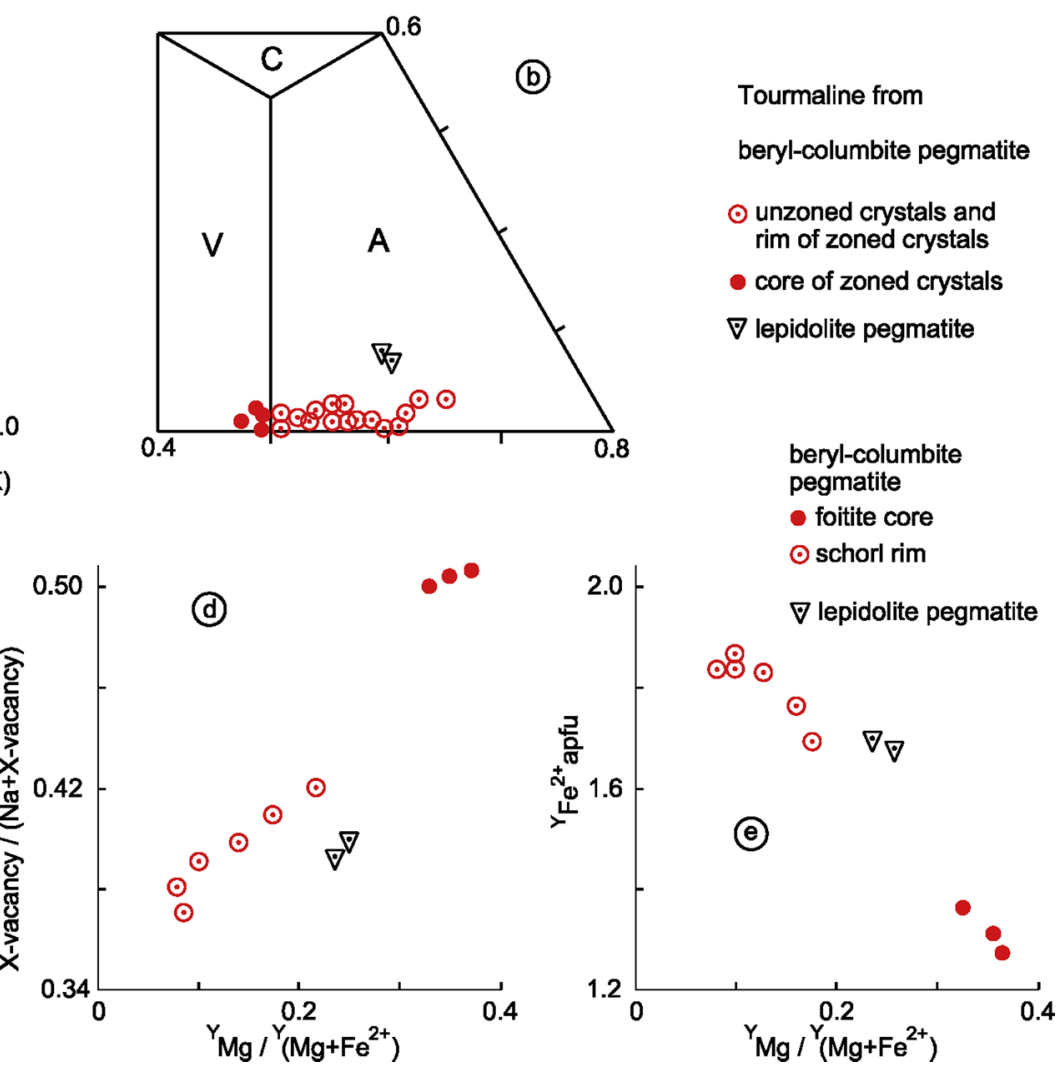

Fig. 9. Tourmaline compositions from granitic pegmatites from the Gravanho-Gouveia area, central Portugal. a. Classification of the principal tourmaline groups based on the X-site occupancy (Henry et al., 2011), showing the location of diagram b, C - calcic group, V - vacancy group, A - alkali group. b. unzoned crystals and rims of other crystals plot in the $\mathrm{Na}(+\mathrm{K})$ group, but cores plot in the vacancy group. c. X-vacancy/(Na $+\mathrm{X}$-vacancy) versus ${ }^{\mathrm{Y}} \mathrm{Mg} /{ }^{\mathrm{Y}}\left(\mathrm{Mg}+\mathrm{Fe}{ }^{2+}\right) \operatorname{diagram}$ distinguishing foitite cores from schorl rims and unzoned schorl crystals. d, e. Compositional variation in zoned crystals from beryl-columbite pegmatites and unzoned crystals from lepidolite pegmatites.

Table 11

Selected chemical data in wt.\% of cassiterite and rutile from lepidolite pegmatites from the Gravanho-Gouveia area, central Portugal.

\begin{tabular}{|c|c|c|c|c|c|c|c|c|c|}
\hline & \multicolumn{4}{|c|}{ Cassiterite } & & \multicolumn{4}{|l|}{ Rutile } \\
\hline & \multirow[t]{2}{*}{$\mathrm{u}$} & \multirow[t]{2}{*}{$\mathrm{d}, 1$} & \multirow[t]{2}{*}{ d } & \multirow[t]{2}{*}{1} & & \multirow[t]{2}{*}{ Homogeneous } & \multicolumn{3}{|c|}{ Heterogeneous } \\
\hline & & & & & & & Darker zone & Lighter Zone & \\
\hline $\mathrm{WO}_{3}$ & - & 0.18 & - & 0.44 & $\mathrm{WO}_{3}$ & 0.16 & 0.21 & 1.77 & 1.80 \\
\hline $\mathrm{Ta}_{2} \mathrm{O}_{5}$ & 6.74 & 1.27 & 0.38 & 3.70 & $\mathrm{Ta}_{2} \mathrm{O}_{5}$ & 0.04 & 6.58 & 6.36 & 9.10 \\
\hline $\mathrm{Nb}_{2} \mathrm{O}_{5}$ & 1.66 & 1.03 & 0.16 & 1.97 & $\mathrm{Nb}_{2} \mathrm{O}_{5}$ & 0.37 & 1.97 & 4.89 & 5.50 \\
\hline $\mathrm{SnO}_{2}$ & 90.17 & 97.32 & 99.74 & 92.84 & $\mathrm{SnO}_{2}$ & 0.58 & 1.12 & 1.46 & 1.28 \\
\hline $\mathrm{TiO}_{2}$ & 0.11 & 0.04 & 0.01 & 0.10 & $\mathrm{TiO}_{2}$ & 98.03 & 87.97 & 81.99 & 78.24 \\
\hline $\mathrm{Bi}_{2} \mathrm{O}_{3}$ & - & 0.02 & 0.06 & 0.04 & $\mathrm{Bi}_{2} \mathrm{O}_{3}$ & - & 0.05 & - & - \\
\hline $\mathrm{FeO}$ & 0.13 & 0.03 & - & 0.06 & $\mathrm{Fe}_{2} \mathrm{O}_{3}$ & 0.40 & 0.75 & 0.46 & 0.18 \\
\hline $\mathrm{MnO}$ & 1.04 & 0.17 & 0.01 & 0.70 & $\mathrm{FeO}$ & - & 1.36 & 2.73 & 3.41 \\
\hline \multirow[t]{2}{*}{ Total } & 99.85 & 100.06 & 100.36 & 99.85 & $\mathrm{MnO}$ & - & 0.02 & - & 0.07 \\
\hline & & & & & Total & 99.58 & 100.03 & 99.66 & 99.58 \\
\hline W & - & 0.001 & - & 0.003 & & & & & \\
\hline Та & 0.046 & 0.009 & 0.003 & 0.025 & $\mathrm{~W}$ & 0.001 & 0.001 & 0.007 & 0.007 \\
\hline $\mathrm{Nb}$ & 0.019 & 0.012 & 0.002 & 0.022 & $\mathrm{Ta}$ & - & 0.025 & 0.025 & 0.037 \\
\hline $\mathrm{Sn}$ & 0.904 & 0.970 & 0.994 & 0.926 & $\mathrm{Nb}$ & 0.002 & 0.013 & 0.032 & 0.037 \\
\hline $\mathrm{Ti}$ & 0.002 & 0.001 & - & 0.002 & Sn & 0.003 & 0.006 & 0.008 & 0.008 \\
\hline $\mathrm{Bi}$ & - & - & - & - & $\mathrm{Ti}$ & 0.990 & 0.931 & 0.890 & 0.866 \\
\hline $\mathrm{Fe}$ & 0.003 & 0.001 & - & 0.001 & $\mathrm{Bi}$ & - & - & - & - \\
\hline $\mathrm{Mn}$ & 0.022 & 0.004 & - & 0.015 & $\mathrm{Fe}^{3+}$ & 0.004 & 0.008 & 0.005 & 0.002 \\
\hline \multirow[t]{3}{*}{ Total } & 0.996 & 0.998 & 0.999 & 0.994 & $\mathrm{Fe}^{2+}$ & - & 0.016 & 0.033 & 0.042 \\
\hline & & & & & $\mathrm{Mn}$ & - & - & - & 0.001 \\
\hline & & & & & Total & 1.000 & 1.000 & 1.000 & 1.000 \\
\hline
\end{tabular}

u - unzoned, d, 1 - average of darker and lighter zone, d - darker zone, 1 - lighter zone in backscattered images; - not detected. Cation formula of cassiterite and rutile based on 6 and 2 atoms of oxygen, respectively. 


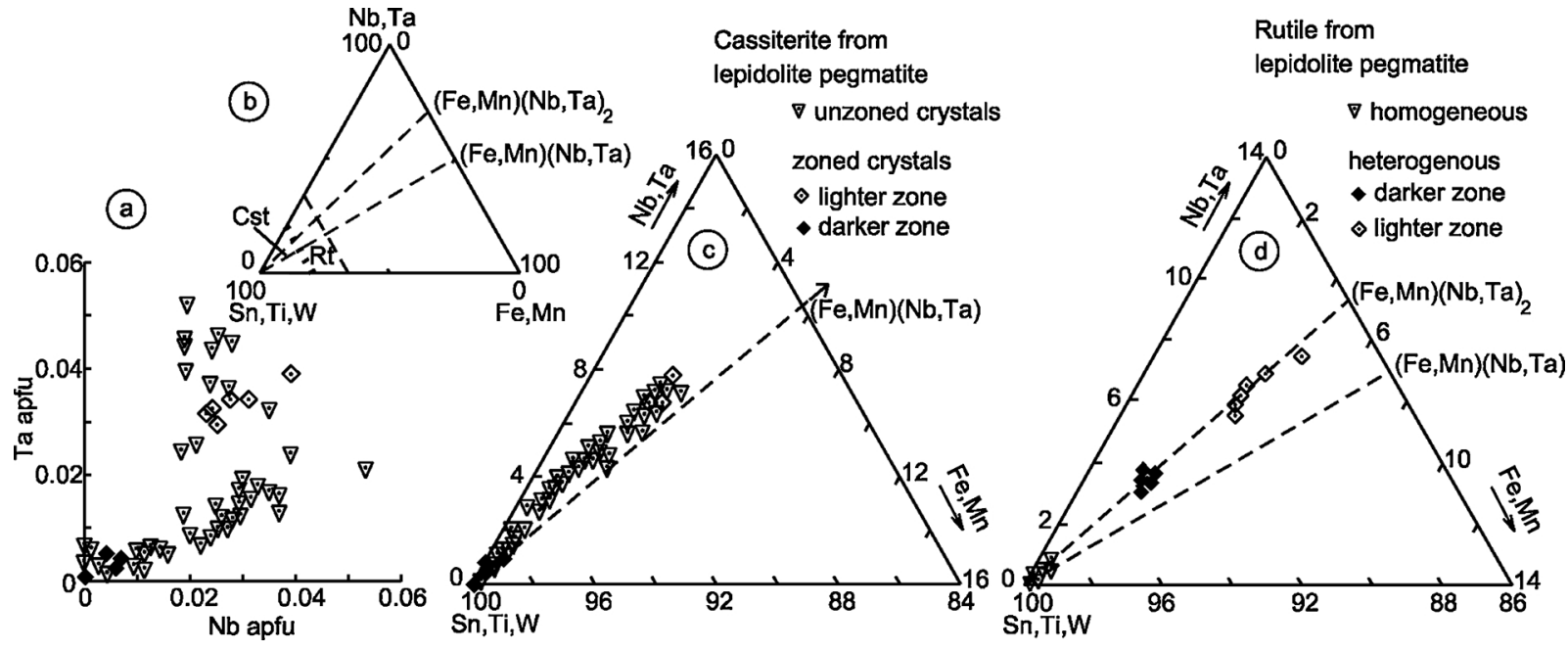

Fig. 10. Diagrams for cassiterite and rutile from lepidolite pegmatites from the Gravanho-Gouveia area, central Portugal. a. Ta versus Nb diagram for cassiterite. b. (Nb, Ta) - (Fe, Mn) - (Sn, Ti, W) diagram showing the location of diagrams c for cassiterite (Cst) and d for rutile (Rt). c. The compositions of cassiterite plot close to the trend for the ideal substitution. d. Compositions of rutile plot close to the $(\mathrm{Fe}, \mathrm{Mn})(\mathrm{Nb}, \mathrm{Ta})_{2}$ join.

\section{Acknowledgments}

Thanks are due to M. Machado Leite for most of the analytical data on aplite-pegmatites and their minerals obtained at LNEG; F. Guimarães for helping to get electron microprobe data at LNEG; F. Longstaffe for the determination of oxygen isotope data; M. Rieder for the use of his computer program for micas. We are grateful to Alex Deutsch, Tomas Magna, K. Breiter, E. Roda-Robles and an anonymous reviewer for their helpful suggestions. This research was financially supported by the FCT project UID/GEO/04035/2013.

\section{References}

Antunes, I.H.R., Neiva, A.M.R., Ramos, J.M.F., Silva, P.B., Silva, M.M.V.G., Corfu, F., 2013. Petrogenetic links between lepidolite-subtype aplite-pegmatites, aplite veins and associated granites at Segura (Central Portugal). Chem. Erde 73, 323-341.

Aurisicchio, C., Fioravanti, G., Grubessi, O., Zanazzi, P.F., 1988. Reappraisal of the crystal chemistry of beryl. J. Bone Miner. Res. 73, 826-837.

Bea, F., 1996. Residence of REE, Y, Th and U in granites and crustal protoliths: implications for the chemistry of crustal melts. J. Petrol. 77, 521-552.

Bongiolio, E.M., Renac, C., Piza, P.A.T., Schmitt, R.S., Mexias, A.S., 2016. Origin of pegmatites and fluids at Ponta Negra (RJ, Brazil) during late- to post-collisional stages of the Gondwana assembly. Lithos 240-243, 259-275.

Breiter, K., Gardenová, N., Vaculovič, T., Kanický, V., 2013. Topaz as an important host for Ge in granites and greisens. Mineral. Mag. 77, 403-417.

Castro, A., Corretgé, L.G., De La Rosa, J., Enrique, P., Martinéz, F.J., Pascual, E., Lago, M., Arranz, E., Galé, C., Fernández, C., Donaire, T., López, S., 2002. Paleozoic magmatism. In: Gibbons, W., Moreno, M.T. (Eds.), The Geology of Spain. Geol. Soc., London, pp. 117-153.

Černý, P., Ercit, T.S., 2005. The classification of granitic pegmatites revisited. Can. Mineral. 43, 2005-2026.

Černý, P., Meintzer, R.E., Anderson, A.J., 1985a. Extreme fractionation in rare-element granitic pegmatites: selected examples of data and mechanisms. Can. Mineral. 23, $381-421$.

Černý, P., Roberts, W.L., Ercit, T.S., Chapman, R., 1985b. Wodginite and associated oxide minerals from the Peerless pegmatite, Pennington County, South Dakota. Am. Mineral. 70, 1044-1049.

Černý, P., Anderson, A.J., Tomascak, P.B., Chapman, R., 2003. Geochemical and morphological features of beryl from the Bikita granitic pegmatite. Zimbabwe. Can. Mineral. 41, 1003-1011.

Černý, P., Masau, M., Good, B.E., Ferreira, K., 2005. The Greer Lake leucogranite, Manitoba, and the origin of lepidolite-subtype granitic pegmatites. Lithos 80, 305-321.

Clayton, R.N., Mayeda, T., 1963. The use of bromine pentafluoride in the extraction of oxygen from oxides and silicates for isotopic analysis. Geochim. Cosmochim. Acta 27, 47-52.

Farias, P., Gallastegui, G., González Ladeiro, F., Marquínez, J., Martín-Parra, L.M., Martínez Catalán, J.R., Maciá, Pablo, de, J.G., Rodríguez-Fernandéz, L.R., 1987. Aportaciones al conocimiento de la litoestratigrafía y estrutura de Galicia Central. Mem. Museu e Lab. Miner. Geol., Fac. Ciências, vol. 1. Univ. Porto, pp. 411-431.

Hawthorne, F.C., 1996. Structural mechanisms for light-element variations in tourmaline. Can. Mineral. 34, 123-132.
Hawthorne, F.C., Huminicki, D.M.M., 2002. The crystal chemistry of beryllium. In: In: Grew, E.S. (Ed.), "Beryllium: Mineralogy, Petrology and Geochemistry" 50. pp. 333-403 Rev. Miner. Geochem.

Henry, D.J., Novák, M., Hawthorne, F.C., Ertl, A., Dutrow, B.L., Uher, P., Pezzotta, F., 2011. Nomenclature of the tourmaline-subgroup minerals. Am. Mineral. 96 895-913.

Leal Gomes, C., 2010. A qualificação gemológica de algumas variedades de minerais pegmatíticos e hidrotermais em Portugal. Ciências Geológicas - Ensino e Investigação e sua História. cap.1. Cristalografia e Mineralogia, vol. 1. pp. 55-67.

Lechler, P.J., Desilets, M.O., 1987. A review of the use of loss on ignition as a measurement of total volatiles in whole-rock analysis. Chem. Geol. 63, 341-344.

London, D., 2008. Pegmatites 10 The Canadian Mineralogist Special Publication 347 p. London, D., Morgan, G.B.V.I., 2012. The pegmatite puzzle. Elements 8, 263-268.

London, D., Černý, P., Loomis, J.J., Pan, J.J., 1990. Phosphorus in alkali feldspars of rareelement granitic pegmatites. Can. Mineral. 28, 771-786.

Mittlefehldt, D.W., Miller, C.F., 1983. Geochemistry of the Wash Pluton, California: implications for "anomalous" trace element behaviour during differentiation of felsic magmas. Geochim. Cosmochim. Acta 47, 109-124.

Neiva, A.M.R., 1996. Geochemistry of cassiterite and its inclusions and exsolution products from tin and tungsten deposits in Portugal. Can. Mineral. 34, 745-768.

Neiva, A.M.R., 2013. Micas, feldspars and columbite-tantalite minerals from the zoned granitic lepidolite-subtype pegmatite at Namivo, Alto Ligonha. Mozambique. Eur. J. Mineral. 25, 967-985.

Neiva, A.M.R., Neiva, J.M.C., 2005. Beryl from the granitic pegmatite at Namivo, Alto Ligonha. Mozambique. N. Jb. Miner. Abh. 18, 173-182.

Neiva, A.M.R., Ramos, J.M.F., 2010. Geochemistry of granitic aplite-pegmatite sills and petrogenetic links with granites, Guarda-Belmonte area, central Portugal. Eur. J. Mineral. 22, 837-854.

Neiva, A.M.R., Silva, M.M.V.G., Gomes, M.E.P., 2007. Crystal chemistry of tourmaline from Variscan granites, associated tin-tungsten- and gold deposits, and associated metamorphic and metasomatic rocks from northern Portugal. N. Jb. Miner. Abh. 184, 45-76.

Neiva, A.M.R., Gomes, M.E.P., Ramos, J.M.F., Silva, P.B., 2008. Geochemistry of granitic aplite-pegmatite sills and their minerals from Arcozelo da Serra area (Gouveia, central Portugal). Eur. J. Mineral. 20, 465-485.

Neiva, A.M.R., Williams, I.S., Ramos, J.M.F., Gomes, M.E.P., Silva, M.M.V.G., Antunes, I.M.H.R., 2009. Geochemical and isotopic constraints on the petrogenesis of Early Ordovician granodiorite and Variscan two-mica granites from the Gouveia area, central Portugal. Lithos 111, 186-202.

Neiva, A.M.R., Silva, P.B., Ramos, J.M.F., 2012. Geochemistry of granitic aplite-pegmatite veins and sills and their minerals from the Sabugal area, central Portugal. N. Jb. Miner. Abh. 189, 49-74.

Neiva, A.M.R., Gomes, C.L., Silva, P.B., 2015. Two generations of zoned crystals of columbite-group minerals from granitic aplite-pegmatites in Gravanho-Gouveia, central Portugal. Eur. J. Mineral. 27, 771-782.

Pesquera, A., Gil-Crespo, P.P., Torres-Ruiz, F., Torres Ruiz, J., Roda-Robles, E., 2016. A multiple regression method for estimating $\mathrm{Li}$ in tourmaline from electron microprobe analyses. Mineral. Mag. 80, 1129-1133.

Pouchou, J.L., Pichoir, F., 1985. "PAP" procedure for improved quantitative analysis. Microsc. Microanal. 20, 104-105.

Roda-Robles, E., Pesquera, A., Gill-Crespo, P., Torres-Ruiz, J., 2012. From granite to highly evolved pegmatite: a case study of the Pinilla de Fermoselle granite-pegmatite system (Zamora, Spain). Lithos 153, 192-207.

Roda-Robles, E., Pesquera, A., Gill-Crespo, P.P., Vieira, R., Lima, A., Garate-Olave, I., Martins, T., Torres-Ruiz, J., 2016. Geology and mineralogy of Li mineralization in the Central Iberian Zone (Spain and Portugal). Mineral. Mag. 80, 103-126. 
Simons, W., Falster, A., Webber, K., Roda-Robles, E., Boudreaux, A., Grassi, L.R., Freeman, G., 2016. Bulk composition of Mt. Mica pegmatite, Maine, USA: implications for the origin of an LCT type pegmatite by anatexis. Can. Mineral. 54, 1053-1070.

Stewart, D.B., 1978. Petrogenesis of lithium-rich pegmatites. Am. Mineral. 63, 970-980. Tertian, R., Claisse, F., 1982. Principles of quantitative X-ray fluorescence analysis. Heyden \& Son Ltd., U.K. 355.

Tindle, A.G., Breaks, F.W., Selway, J.B., 2002. Tourmaline in petalite-subtype granitic pegmatites: evidence of fractionation and contamination from the Pakeagama Lake and Separation Lake areas of northwestern Ontario, Canada. Can. Mineral. 49, $753-788$.
Tischendorf, G., Gattesman, B., Förster, H.-J., Trumbull, R.B., 1997. On Li-bearing micas: estimating Li from electron microprobe analyses and an improved diagram for graphical representation. Mineral. Mag. 61, 809-834.

Tischendorf, G., Rieder, M., Förster, H.J., Gottermann, B., Guidotti, C.V., 2004. A new graphical presentation and subdivision of potassium micas. Mineral. Mag. 68 , 649-667.

White, A., 2003. High temperature applications. II. Oxygen isotopes as an indicator of assimilation. Geology 656 Isotope Geochemistry. Lecture 30, 227-231.

Whitney, D.L., Evans, B.W., 2010. Abbreviations for names of rock-forming minerals. Am. Mineral. 95, 185-187. 